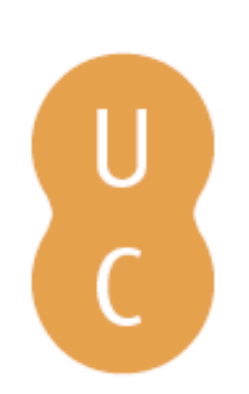

\title{
nombalina
}

\section{Amor na sátira de Horácio e seus predecessores}

Autor(es): Oliveira, Francisco de

Publicado por: Centro de Estudos Clássicos e Humanísticos; Imprensa da Universidade

URL

persistente: URI:http://hdl.handle.net/10316.2/32040

DOI: $\quad$ DOI:http://dx.doi.org/10.14195/978-989-8281-11-1_3

Accessed : $\quad$ 26-Apr-2023 12:10:15

A navegação consulta e descarregamento dos títulos inseridos nas Bibliotecas Digitais UC Digitalis, UC Pombalina e UC Impactum, pressupõem a aceitação plena e sem reservas dos Termos e Condições de Uso destas Bibliotecas Digitais, disponíveis em https://digitalis.uc.pt/pt-pt/termos.

Conforme exposto nos referidos Termos e Condições de Uso, o descarregamento de títulos de acesso restrito requer uma licença válida de autorização devendo o utilizador aceder ao(s) documento(s) a partir de um endereço de IP da instituição detentora da supramencionada licença.

Ao utilizador é apenas permitido o descarregamento para uso pessoal, pelo que o emprego do(s) título(s) descarregado(s) para outro fim, designadamente comercial, carece de autorização do respetivo autor ou editor da obra.

Na medida em que todas as obras da UC Digitalis se encontram protegidas pelo Código do Direito de Autor e Direitos Conexos e demais legislação aplicável, toda a cópia, parcial ou total, deste documento, nos casos em que é legalmente admitida, deverá conter ou fazer-se acompanhar por este aviso.

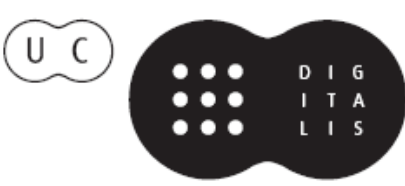




\section{Horácio \\ e a sua \\ Perenidade}

\section{Maria Helena Rocha Pereira, José Ribeiro Ferreira e Francisco de Oliveira}

IMPRENSA DA UNIVERSIDADE DE COIMBRA 


\title{
Amor na sátira de Horácio e seus predecessores
}

\author{
Francisco de Oliveira \\ Universidade de Coimbra
}

\section{Introdução}

Entre a obsessão por um objecto único de um amor apaixonado, representada por Catulo, e a satisfação do desejo sexual com parceiros ocasionais, de forma não emotivamente empenhada, defendida por Lucrécio nos finais da República, optámos por analisar o tratamento satírico do tema do amor em Lucílio, Lucrécio e Horácio, sem prejuízo de alguma atenção prestada a outros poetas, e em especial a Ovídio, preferentemente remetidos para apontamentos nas notas ${ }^{1}$.

\section{Lucílio}

\subsection{Amor como doença}

A concepção do amor em Lucílio, o primeiro satirista europeu no sentido moderno do termo ${ }^{2}$, inclui topoi habituais: o amor como morbus 'doença' (fr.29.15 $=803 \mathrm{M}$ e fr.29.77 = 857-8 M), o amor como insania (fr.27.27=732M), a caracterização do apaixonado com o adjectivo miser 'infeliz, desgraçado'(fr.29.46 $=914 \mathrm{M})^{3}$, a distinção entre cupiditas e cupido (fr.29.1 = 806-7M), os paradoxos da paixão (fr.30.75 = 1097M: mite malum, blandum atque dolosum 'um mal doce, sedutor e enganador $)^{4}$, a necessidade de procurar cura $(\text { fr. } 29.77=857-8 \mathrm{M})^{5}$.

Um dos tópicos da doença do amor é a cegueira, porventura implícita no fr.7.9 $=267 \mathrm{M}^{6}$, onde também se refere a perda do olfacto.

${ }^{1}$ Para as duas principais correntes sobre o amor no final da República, ver Arkoms 1993: 106 (confronto entre Lucílio e Catulo), Rudd 1966, esp. 122-124; para a relação entre Horácio e neotéricos, cf. Propércio, 2.34.85-94, e Lefèvre 1993: 106 ss.; para a crítica de Horácio ao amor exclusivo de elegíacos como Propércio (e. g. 2.13.36: unius seruus amoris; e 2.20) e Tibulo, cf. Arkins 1993: 108-110 e 115. Em Horácio, limitei-me às sátiras, não ignorando que as odes partilham muito da temática aqui presente (cf. C.3.7 sobre os perigos do adultério). A meu ver, o tratamento paródico e satírico faz parte da tradição erótica, com representação na Antologia Palatina e em elegíacos como Catulo e Ovídio, o que logo se compreende em função da existências de rivais, de falta de correspondência ou de obstáculos a invectivar; Gutzwiller 1998: 170-182 relaciona com o ambiente simposíaco e ilustra com Ar. V.1224-1248.

${ }^{2}$ Brown 1993: 7. Os fr. de Lucílio estão citados pela edição de Charpin, com correspondência a Marx.

${ }^{3}$ Ver também Lucr. 4.1159, Catulo, 8 e 76.12, Tib. 1.8.53 e 61, Prop. 1.5. Precedente em P1. Merc. 18-62, 355-359, 588-590.

${ }^{4}$ Cf. Catulo, 51 (ideia subjacente ao carme) e 76.25; Lucr. 4.1141: Atque in amore mala; Prop. 3.17.10. Amor como doença é um lugar-comum que a literatura latina conhece profusamente desde a comédia: cf. M. Flury 1986: 57 e 70 ss., 88 ss.

${ }^{5}$ Não encontro fundamento para ir além desta interpretação e ver aqui, com Fiske 1966: 261 e 296, referência a paixão por matronas.

${ }^{6}$ Fiske 1966: 267. 
O amor pode ser fonte de tormento e incerteza, como se depreenderá do fr. 27.20 = 734M: Ego enim an perficiam ut me amare expediat? 'Será que eu chegarei a fazer com que me venha a amar?', e do fr.27.25 = 731M: Iam, qua tempestate uiuo, certe sine: ad me recipio 'Pela aflição em que vivo, pois tem lá paciência; vou meditar comigo mesmo!?

No aspecto psicológico, o amante é classificado como insanus ${ }^{8}$, cujo comportamento implica submissão à amada (fr.30.73 = 990M: sic laqueis, manicis, pedicis mens inretita est , cf. fr.29.12 = $894 \mathrm{M}$ ); é o caso da Hímnis que desperta paixão avassalora (fr.29.12 = 894M: quod tu ab insano auferas 'o que tu de um perdido de amor podes obter', uma Hímnis dotada de um rosto que é uma beleza em flor (fr.H. $80=1115-6 \mathrm{M})$, capaz de encantar (adseruisse) como por cantos mágicos (fr.H.80-81 = 1115-6 e 1193M) ${ }^{10}$.

O tema do exclusus amator liga-se à servidão amorosa e ao paraklausithyrion 'junto de uma porta fechada' nos fr.29.51-56 = 845M, que testemunham uma tentativa de arrombamento.

Para além destas expressões, cuja carga semântica implica atracção, submissão e simpatia, o nexo entre beleza e amor é explicitado no fr.27.21 = 735M: at metuis porro ne aspectu et forma capiare altera 'Mas então receias ser seduzido por uma outra, pela sua aparência e beleza' ${ }^{11}$.

O mesmo tópico se encontra no fr.27.31 = 306M, com a anotação de que beleza atrai amor: illo oculi deducunt ipsi atque animum spes illuc rapit ${ }^{`}$ Para onde os seus olhos se desviam, para aí a esperança o arrebata' ${ }^{\prime 2}$.

O mal de amor assume a forma de servidão amorosa, presente nos termos adseruire, que encontrámos anteriormente, e praeseruire, que ocorre num passo onde, para além dos antecedentes na comédia latina (Plauto, Anfitrião, 124: praeseruire amanti meo), se antevê o lado feminino do seruitium amoris: praeseruit, labra delingit, delenit amore 'mostra-se sua escrava, lambe-lhe os lábios, desfaz-se em amor' (fr.30.74 = 1004M) ${ }^{13}$.

${ }^{7}$ A expressão final, ad me recipio, aparece em P1. Mil.230 e de Ter. Hau.1056.

${ }^{8}$ Cf. AP 5.112, onde Filodemo implica o conceito de mania; D. Konstan 1986: 372: "The equation of love with madness was proverbial at Rome".

${ }^{9}$ Veja-se fr.29.1 = 806-7M; Ovídio, Ars 1.372: et insano iuret amore mori (cf. Prop. 2.1.47: laus in amore mori); o motivo da morte por amor e do amor como doença ou loucura é frequente na comédia (cf. P. Flury 1988 passim) e nos elegíacos, como escreve P. Fedeli em P. Fedeli - A. Nascimento 2002: 17 ss.

${ }^{10} \mathrm{O}$ termo rosto (facies) recorre no fr.30.85 =1039-1040M: uultu ac facie; a referência aos cantos mágicos evoca a VIII Bucólica de Virgílio.

${ }^{11}$ Cf. fr.27.31 = 706M: illo oculi deducunt ipsi atque animum spes illuc rapit Para ali seus próprios olhos o desviam e a esperança para aí o empurra'. O fr. $8.6=296-297 \mathrm{M}$ parece deixar entrever um ideal andrógino de beleza, tal como fr.4.10 = 174-176M, segundo G. Williams 1999: 24-25. Já em P1. Merc. 182 e 299, o tema da beleza física suscita o amor, por intermédio do olhar.

${ }^{12} \mathrm{Cf}$. Lucr. 4.1078: nec constat quid primum oculis manibusque fruantur ' $\mathrm{E}$ nem é certo se gozam primeiro com os olhos ou com as mãos'. O tema dos olhos é recorrente nos poetas elegíacos (cf. AP 12.113 e 122, Prop. 4.8.66: praecipueque oculos; Ov. Ep. 15.22).

${ }^{13} \mathrm{O}$ fr.29.47 =918-9M descreve como a amante sabe esgotar o parceiro; para o serviço amoroso feminino, ver Ovídio, Am. 2.17, 3.7.11 e Heroides, 3 (Carta de Briseida a Aquiles). 
O mesmo topos assume tonalidade elegíaca com o título de domina, no fr. 27.24 = 730M: cum mei me adeunt seruuli, non dominam ego appellem meam? 'Na presença dos meus escravos, não hei-de chamar-lhe "senhora minha"? 14

Não falta sequer o melodramático das cenas de violência, ciúme e apaziguamento, onde é o amante que tenta acalmar a ira da amada (fr.27.26 = 729M): Cum pacem peto, cum placo, cum adeo et cum appello meam 'Quando proponho as pazes, quando a acalmo, quando me aproximo e lhe digo "és minha"'15.

Existe mesmo uma metáfora animal para descrever a fúria excessiva, devoradora e autoflageladora da mulher na proximidade do homem, a qual é comparada a um polvo que rói os seus próprios tentáculos (fr.29.79 = 861-2M: paulisper [cui] me dem, iam edet haec se, ut polypus ipsa $)^{16}$.

Esta imagem da mulher irata, em verdadeiro furor, que grande fortuna conhecerá nos poetas elegíacos, recorda outra visão negativa da amada, e em especial da meretrix, a da mulher gastadora (fr.27.28 = 737M: quam non solum deuorare se omnia ac deuerrere 'A qual não só lhe devora tudo como o limpa completamente').

Finalmente, o tema do rapto da amada e, simultaneamente, o topos do paraklausithyrion 'junto de uma porta fechada', acaso já presente nos fr.29.51$54=839-843 \mathrm{M}$, são pressupostos de uma série de fr. próximos, de que cito o fr.28.24 = 773M: malo hercle uestro, confectores cardinum!'Por Hércules, malditos sejais, arrombadores de portas!'

A ideia de militia erótica pode subentender-se no fr.69 = 1323M: Vicimus, o socii, et magnam pugnauimus pugnam ${ }^{17}$.

\subsection{Os perigos, vicios ou inconvenientes do amor}

Entre os perigos do amor encontram-se a dilapidação do património, a perda da boa fama, a inconstância e incerteza que por vezes se traduzem em estados anímicos contraditórios (guerra e paz).

A figura do amante que gasta o património no amor é ocasional, talvez somente visado no fr.30.69 $=1091 \mathrm{M}$ (confici ipse comestque) e sobretudo nos fr. 30.77 e $78=1050-1052 \mathrm{M}$.

Mais frequente se afigura o tema da meretriz que provoca a dilapidação do património (fr.27.28 = 737M; 29.13 = 891-3M; e 30.77 e 78 = 1050-2M), um

${ }^{14}$ Para o serviço amoroso, ver fr.27.29 = 736M: primum qua uirtute <sese> seruitute excluserit 'Antes de mais, com que coragem <se > libertou da servidão!'; cf. Propércio, 1.5.19-22, 1.9.3-4; Tibulo, 2.3.79-80, 2.4.1 ss.; Ovídio, Am.2.17.

$15 \mathrm{O}$ uso do possessivo tem paralelo em Plauto, Poen. 365-368; Terêncio, Eu. 4 55-456: O Thais mea / Meum sauium; Propércio, 1.8 .42 e 44, 2.9.46 (esse tuum).

${ }^{16}$ Para o polvo, o facto é negado por Plin. Nat.9.87; Fiske 1966: 262-263 entende tratar-se de meretrix da segunda classe, com haec a referir-se a património e fama.

${ }^{17}$ Cf. Meleagro AP 5.166; Propércio inverte o cliché em 2.15.3-4: Quam multa apposita narramus uerba lucerna / quantaque sublato lumine rixa fuit!; Marcial 10.38.6-7: O quae proelia, quas utrimque pugnas / felix lectulus et lucerna uidit. 
lugar-comum da misoginia na comédia latina ${ }^{18}$. É essa a ideia transmitida pelo fr.26.49 = 682-3M, onde ganham expressividade os neologismos decalauticare e despeculassere e o jogo etimológico speculo despeculassere:

Depeculassere aliqua sperans me ac deargentassere
decalauticare, eburno speculo despeculassere.

Sempre na esperança de me despojar e de me desendinheirar, de me depenar, de me despelar com um espelho de marfim.

Com o mesmo vitupério atinge Lucílio a matrona rica e viciosa, rodeada de escravos e mercadores (fr.30.88 $=1056-7 \mathrm{M}$ ), andróginos imberbes e exóticos devassos e adúlteros (fr.30.89 = 1058M). Assim, o fr.26.50 = 684-5M retratará uma cena conjugal em que uma mulher gananciosa, e eventualmente adúltera, ao ser contrariada pelo marido, resolve vingar-se dormindo em quarto separado $^{19}$ :

Ferri tantum si roget me, non dem, quantum auri petit; si secubitet, sic quoque a me, quae roget, non impetret.

Não lhe vou sequer dar em ferro quanto me pede em ouro; se dormir à parte, também não vai conseguir o que me está a pedir.

O motivo das separações, saídas e gastos femininos alia-se à sugestão de mentira e, por conseguinte, à suspeição de adultério no fr.30.87 =993-4M"20.

aut cum iter est aliquo et causam commenta viai

aut apud aurificem, ad matrem, cognatam, ad amicam.

Ou quando tem de ir a algum lado e inventa um motivo para a saída: ou o ourives, ou a mãe, uma parente, uma amiga.

No elenco devem também listar-se as saídas por motivos de culto referidas no fr.30.91 $=992 \mathrm{M}$. E ao adultério ajusta-se a conivência de intermediários para encontros amorosos, como no fr. $29.34=835 \mathrm{M}$, num esquema de intervenção que faz lembrar a conciliatrix 'alcoviteira' do fr. 7.5 $=271 \mathrm{M}^{21}$.

${ }^{18}$ Cf. Plauto, Truc. 31-55; Terêncio, Hau. 749-756, só para dar dois exemplos.

${ }^{19}$ Dormir em quarto separado era uma das técnicas para enganar o marido com amantes, como se vê em Tib. 1.6.11.

${ }^{20}$ Tib. 1.9.72 censura uma esposa que gasta remque domumque do marido com um jovem amante.

${ }^{21}$ Existência de intermediários, cúmplices e esquemas de ludíbrio da vigilância reaparecem em Horácio, S. 1.2.130 e 2.7.53-61, Tib. 1.6 (uma verdadeira arte de fingir e ludibriar, onde a própria mãe é conivente da adúltera); cf. 1.8.55-62; 2.1 .75 e 3.12.12: Cupido ensina a arte dos amores furtivos; Prop. 2.6; Ov. Am. 2.2, Ars 1.1.351-398, 3.611-658 e Juv. 6.346-351. 


\subsection{Elogio do amor venal e fácil vs. perigo do adultério com matronas}

O tema do amor saudável, física e psicologicamente, e a baixo custo, fica logo implícito quando se refere a existência de rameiras (fr.H.70 = 1271M: ... Pyrgensia scorta), de tráfico de sexo, atestado pela ocorrência dos termos mercaturae e quaesticuli 'mercadorias, pequenos lucros' 22 , e de prostitutas com múltiplos parceiros ${ }^{23}$.

Essa mesma teoria estará implícita no fr.H. $56=1316 \mathrm{M}$, onde a expressão Valeri sententia dia, que seria uma paródia de Énio ${ }^{24}$, parece ser o correspondente à sententia dia Catonis, de Horácio S. 1.2.32, com que o Censor elogia um jovem que sai do fornix 'prostíbulo'. De resto, uma das sátiras de Lucílio teria exactamente o título de Forni ${ }^{25}$, termo cujo sentido erótico pode encontrar-se no fr.7.15 = 291M: Primum fulgit, uti caldum ex furnacibus ferrum 'Primeiro refulge como ferro em brasa das fornalhas'.

Não falta sequer a perspectiva cínica da satisfação sexual sem parceiro, com o fr. $8.4=307 \mathrm{M}$ a aludir à masturbação: at laeua lacrimas muttoni absterget amica 'Com a ajuda da mão esquerda, espalha as lágrimas do maganão' (ver fr. $30.23=1031 \mathrm{M})^{26}$.

Num certo número de fragmentos, o tratamento do tema assume toada elegíaca, logo com o vocabulário sexual, incluindo os diminutivos, o uso de grecismos e o tema da mulher que finge prazer. Trata-se, a meu ver, de amor comprado, para satisfazer necessidade compulsiva e imediata, acaso em bordel $(\text { fr.8.1 = 303-4M })^{27}$ :

\section{Cum poclo bibo eodem, amplector, labra labellis}

Fictricis conpono, hoc est cum psolokopoumai.

Quando bebo pelo mesmo copo, a beijo, com meus lábios esmago os lábios da fingedora, isto é, quando me esporro.

Outros passos (fr.8.2-3 = 305-6M) deixam entrever cenas de contacto físico cujo vocabulário é da praxe na descrição dos jogos de sedução e de amor venal e extra-conjugal em autores passados e vindouros ${ }^{28}$ :

${ }^{22}$ Fr.8.15=318M; cf. Fiske 1966: 259-260; o sexo pago é assinalado por qualquer dos étimos tanto na comédia como nos elegíacos (cf. Prop.2.16.16: indigna merce puella perit!).

${ }^{23}$ Fr.SN.6 = 936-937M: existência de sexo parabilis; cf. fr.H.74 = 1267M; ver AP 5.109.

${ }^{24}$ Brown 1993 ad 31-32.

${ }^{25}$ Fiske 1966: 256 abona com Arnóbio e Marx ad fr.1187M. Ver recorrência de fornix em Hor. S.1.2.30-31 (olenti in fornice) e Juv. 11.172-173 (olido ... fornice); cf. Prop. 2.23.10: immunda casa.

${ }^{26}$ Cf. AP 12.22 e Oltramare 1926 para a tese cínica 32d, sobre prazeres solitários.

${ }^{27} \mathrm{O}$ uso de grecismos na linguagem amorosa já se encontra em Plauto e será retomado por Lucrécio, 4.1160-1169. Seria fastidioso indicar as aproximações vocabulares com a linguagem erótica da elegia latina (um único exemplo: Ov. Am. 3.14.23: condatur lingua labellis); sobre o prazer fingido, cf. Lucr. 4.1192 (Nec mulier semper ficto suspirat amore) e Prop. 2.24.47 (Dura est quae multis simulatum fingit amorem); cf. Fiske 1966: 269.

${ }^{28}$ Veja-se Anacreonte, fr.439 PMG "Entrosando coxas noutras coxas" (trad. F. Lourenço, Poesia Grega de Álcman a Teócrito, Lisboa, 2006), e numerosos paralelos na Antologia Palatina. 
Horácio e a sua perenidade

Tum latus conponit lateri et cum pectore pectus

$\leftrightarrow->$ et cruribus crura diallaxon

Então um flanco esmaga outro flanco, peito contra peito.

$<->$ e entrecruzando perna com perna.

Fica ainda implícita a ideia de orgia da paixão que destrói e aniquila o homem (fr.29.47 = 918-9M):

Concedat homini id quod uelit, deleniat!

Corrumpat prorsum ac neruos omnis eligat!

Dê a esse sujeito o que ele quiser, seduza-o!

Rebente-o por completo e derreta-o até à medula!

Finalmente, será possível admitir que no fr.27.21 =735M existe incitamento a uma Venus multiuaga, solução recusada por um amante desiludido, que tem receio de outra vez se apaixonar ${ }^{29}$.

Um outro indício de relacionamento com prostitutas é o tema do nu feminino exposto por vontade própria, profissionalmente, como quando Creteia faz serviço domiciliário e se despe por livre iniciativa, sem delongas ${ }^{30}$; ou a nudez como revelação da mercadoria exposta para venda, com toda a beleza a descoberto, como no fr.29.21 = 816M (filum non malum 'um perfil nada mau!'), ou no fr.SN.3 = 940-1M, onde o vulgarismo de origem helénica remete para ambiente de lupanar: Hymnis <si> sine eugio, / hanc destina 'Hímnis, mesmo sem sexo / ... arremata-a!'31.

Noutros passos deduz-se o elogio da uma beleza feminina que é exposta para ser inclusive comprovada (cf. H.65 = 1296M: si facie facies praestat, si corpore corpus). Pode mesmo pensar-se numa situação em que uma meretriz é examinada, ou até apalpada, para ver se serve, como nos fr.4.10 =174-6M e $29.78=859-860 \mathrm{M}$, respectivamente:

Quod si nulla potest mulier tam corpore duro

esse, tamen tenero maneat succusque lacerto

et manus uberi<or> lactanti in sumine sidat.

Hic corpus solidum inuenies, hic stare papillas pectore marmoreo.

Ora se nenhuma mulher consegue ser tão rija de corpo, pelo menos que o viço ${ }^{32}$ permaneça nos seus membros delicados, e as mãos fiquem < bem> cheias com suas lácteas tetas.

${ }^{29}$ Cf. F. Charpin, nota complementar ad loc.

${ }^{30}$ Fr.SN2 = 925-7M; cf. fr.SP11 = 933-934M: uestimenta $\ldots$ reposueram .

31 Eugium é jargão, tal como cunnus, que reencontramos em Hor. S. 1.2.70: ver J. Adams 1982 s.v.

${ }^{32}$ Fraseologia semelhante em Terêncio, Eu. 318: Color verus, corpus solidum et suci plenum; Marcial, 14.134. 
Nesta encontrarás um corpo rijo, umas mamas bem firmes num peito de mármore.

Em contrapartida, sugere-se que algumas matronas procuram esconder os defeitos sob múltiplos atavios, com Lucílio a desmistificar os tradicionais estereótipos e mitos do feminino, como Alcmena e Helena, num trecho que utiliza uma apurada técnica de contraposição de termos e até de epítetos épicos, e em grego ${ }^{33}$, bem como expressões prosaicas em latim. A invectiva recai em especial sobre Helena, deixando-se ao critério do leitor escolher o derrogativo que lhe apraza para a classificar - lupa 'loba', moecha 'adúltera', scortum 'puta, rameira' (fr.17.2 = 540-546M):

\author{
nunc censes kalliplókamon, kallísphyron illam \\ non licitum esse uterum atque etiam inguina tangere mammis? \\ conpernem aut uaram fuisse Amphithryonis akoitin \\ Alcmenam, atque alias, Helenam ipsam denique - nolo \\ dicere: tute uide atque disyllabon elige quoduis - \\ kouren eupatereiam aliquam rem insignem habuisse \\ uerrucam, naeuum, rictum, dentem eminulum unum?
}

Vais agora pensar que a célebre beldade aux jolies tresses, aux jolies talons, não podia ter mamas que lhe chegavam até ao umbigo e mesmo até às virilhas? Que não tinha pernas cambas ou tortas a madame de Anfitrião,

Alcmena, e que outras, e até a própria Helena - e não serei eu a classificá-la: avia-te tu e escolhe as duas sílabas que quiseres essa demoiselle aux nobles ancêtres, não tinham alguma mazela, uma verruga, um sinal, um lábio arreganhado, um dente saliente? ${ }^{34}$

${ }_{33}$ Por facilidade, grafei em caracteres latinos os termos gregos, no geral homéricos: kalliplokamon refere-se a Deméter (Il.14.326), a Tétis (Il.18.207 e 407) e a Ariadne (Il.18.592); kallisphyron reporta-se a Marpessa (Il. 9.557 e 560), a Dânae (Il.14.319), a Ino (Od. 5.333) e a Hebe (Od.11.603); akoitin é termo frequente para esposa, pertencendo a Helena, Alcmena, Andrómaca e a várias outras figuras (cf. Il. 3.138, 6.374, Od.11.266; Hes. Th. 999); kouren é de uso muito frequente, reportando-se ocasionalmente a Helena (Od.3.227); eupatereiam é epíteto de Helena (Il. 6.292 e 22.227) e de Tiro (Od. 11.235). Cf. grecismo euplocamo ... capillo no fr.30.92 = 991M, referente a uma matrona. Autores posteriores seguirão a mesma técnica, como escreve R. Brown 1987: 131: "it was probably he from whom Lucretius learned the technique of juxtaposing fanciful Greek and realistic Latin terms (a feature which he obviously cannot have borrowed from a Greek author)"; variações sobre o tema: AP 5.121, de Filodemo, sobre amada de tez escura, que não é a mais bela; Ov. $A m \cdot 2 \cdot 4.9-48$ (a todas ama, sem cânone fixo de beleza); Ars 2.641-662 (conveniência de ignorar os defeitos da amada, passo de tonalidade lucreciana; cf. 3.261-280: Ovídio a todas ensina a arte de amar, bonitas e feias, especialmente a estas, pois raro é o rosto que não tem defeitos).

${ }^{34}$ Comparar dentem eminulum unum com $3.13=117-8 \mathrm{M}$ : Broncus Bouillanus dente aduerso eminulo bic est, / rinoceros; cf. Ovídio, Ars 3.279-280. O uso de galicismo para traduzir o grego também foi utilizado por Rudd 1966: 26 em relação a Lucrécio, 4.1160 ss. Sobre a cegueira dos amantes, veja-se Lucr. 4.1141-1191; Hor. S.1.3.39; paródia do tema em Prop. 2.22.20: numquam ad formosas caecus ero; Ov. Rem. 291-356 e 699-706. O topos pode relacionar-se com a discussão de valores e conceitos, como em Platão R. 559-561, Hor. S.1.341-54; Juv.14.107 ss. 
Mas, quanto a defeitos, e tendo em conta a cegueira dos amantes, também se não nega que eles são por vezes o princípio da atracção (fr.30.82 = 1068M): contra haec inuitasse aut instigasse uidentur 'Á contrário, parece que foram esses defeitos que o atraíram, o espicaçaram ${ }^{35}$.

\subsection{Perigos do adultério}

No adultério só há perigos se houver adúlteros ... e adúlteras. Ora, como já entrevimos, em questão de adultério, as matronas coevas não eram pecas. Assim, se o fr. $30.60=996 \mathrm{M}$ se refere a um marido que andou em viagem por mar para, no regresso, lhe ser barrada a porta de entrada em sua própria casa, por não ser reconhecido ou ser julgado morto (fr.30.63-65 = 1002, 1003 e $1007 \mathrm{M})$, então, além de uma variante irónica sobre o tema do paraklausithyrion, teríamos uma história de quebra do pudor por parte de esposa com marido ausente (fr.30.67 e 68 = 1049 e $1048 \mathrm{M})$ :

quandoque pudor ex pectore cessit, ...

sublatus pudor omnis, licentia fenus refertur.

e quando o pudor desaparece do nosso coração...

suprimido todo o pudor, a desvergonha é tida como investimento!

Mesmo exemplos como o de Penélope são controvertidos (fr.30.84 = 997M: Penélope proclamaria fidelidade a Ulisses; fr.17.2 = 540-6M: a Penélope seriam indicados defeitos de grandes matronas $\left.{ }^{36}\right)$. Fica mesmo implícita a sugestão de que se vendiam como prostitutas $(\text { fr.29.81 }=868-9 \mathrm{M})^{37}$ :

At non sunt similes, neque dant-Quid? Si dare uellent acciperesne? Doce!

“Mas estas não são desse tipo e não se dão!" - "Como?! Se se dessem, aceitavas ou não? Diz-lá”.

Consequentemente, se as casadas aceitavam relações extra-conjugais, é natural que estalasse a controvérsia sobre os perigos inerentes, em face da legislação repressiva existente.

${ }^{35}$ Cf. Lucrécio, 4.1278-1282 (por vezes o amor recai sobre mulher de pouca beleza); Hor. $S$. 1.3.38-40 (cegos de amor, os apaixonados não só não vêem os defeitos como até se comprazem com eles) e 1.2.80 ss. (os defeitos das matronas estão ocultos, os das não livres não podem ser escondidos); na linha de Lucr. 4.1171-1190, Ovídio, Rem. 291-356, em clara evocação de Lucrécio, advoga a observação objectiva, e de improviso, dos defeitos e mazelas da amada como remédio para a paixão.

${ }^{36}$ Cf. Fiske 1966: 403-404; Rudd 1966: 234 ss.

37 Para além da latomia de adultério de matronas nos elegíacos, implícita no já versado motivo dos perigos do adultério, recordo somente Prop. 3.3.47-50, 3.13.23-34 e Marcial, 4.7. A sugestão de prostituição de casada encontra-se também na togata: ver F. Oliveira, "Misoginia na comédia togata", Lisboa, no prelo. 
Ora, se o fr.7.13 = 278M descreve movimentos sexuais de um homem e de uma mulher (Hunc molere, illam autem ut frumentum uannere lumbis 'ele a moer, e ela a amassar a farinha com os rins"), não é impossível interpretar as duas orações infinitivas, com Fiske 273, na linha de Marx, como cena de adultério descoberto em flagrante pelo marido. Todavia, os movimentos voluptuosos referidos normalmente referem-se a prostitutas, tal como a colocação da mulher por cima do homem no fr.H.66 = 1297M: Si uero das quod rogat et si suggeri' suppus ${ }^{38}$.

E se aceito que o fr.29.75 $=854-855 \mathrm{M}$ possa supor um marido que ameaça deportar um adúltero (fugitiuum deportem), e que, no fr.29.74 = 856M, os termos tela e insidias signifiquem perigos para o adúltero, até ratoeiras armadas pela mulher cobiçada ${ }^{39}$, o passo também pode referir-se a uma meretrix, tanto mais se for verdade que conuentus se aplica a um amante despedido, como nota Charpin.

Já me parece mais provável que os perigos do adultério sejam convocados no fr. $29.35=905 \mathrm{M}$ (cuius si in periclo feceris periculum) e, em tonalidade que encontraremos na lírica e na sátira latinas, com defesa de amores vulgares e de uma Vénus errática, como dissuasão do adultério com matronas, no fr.29.76 $=863-5^{40}$ :

nunc tu

contra uenis, vel qui in nuptis uoluisse neges te, nec sine permitie!

Agora tu

estás contra, chegas a dizer que nunca quiseste nada com casadas, e que não é coisa sem perigos!

Congruentemente, a necessidade de compatibilizar a satisfação de necessidades sexuais prementes com a salvaguarda da moral pública, isto é, com a honra das mulheres honestas (ver ocorrência de flagitium), implica defender "sexo seguro", quer dizer, com não casadas, sendo preferível recorrer a prostitutas ou até a prostitutos $(\mathrm{fr} .29 .80=866-7 \mathrm{M})^{41}$ :

${ }^{38}$ Sobre supinus / suppus, ver Adams 1982: 192, que, na p.48 discute o conceito de lumbus, por vezes usado como "euphemism for a sexual organ", com sugestão de movimentos eróticos, em linha com as teorias que consideravam residir nos rins o prazer sexual (cf. Prop.2.16.27). De qualquer modo, a expressão sublatis lumbis 'os rins soerguidos' aparece em contexto de sexo conjugal more ferarum em Lucr. 4.1267. Ver infra n.107.

${ }^{39}$ Fiske 1966: 262; cf. Tib. 1.6.3-5: insidias ... casses; Prop. 2.32. 19-20.

${ }^{40}$ Discussão do passo em Fiske 1966: 260-261, onde todavia não me parece demonstrado que sine permitie se possa referir a amor com libertas, a segunda classe de amantes de Horácio. Cf. Lucrécio, 4.1058-1072 (elogio da uuluigaua Venus); Hor. S.1.2; Prop., 2.23, 2.24: amores vis trazem menos infâmia e menos despesa.; Ov. Am.2.19 (irrisão do motivo: não se agrada nem de amor fácil nem de marido alcoviteiro), Ars 1.382 (perigo de o jovem amante ser apanhado); cf. Juvenal 3.62-100: invasão de rameiras vindas do oriente.

${ }^{41}$ Fiske 1966: 272 interpreta o passo como "love of the girls in the brothel". De qualquer forma, o recurso à prostituição, e em especial a prostitutas baratas, para não dilapidar o património, tem longa tradição na literatura latina, desde Catão (Horácio, S.1.2.28-36) a Plauto, 
Qui et poscent minus et praebebunt rectius multo
et sine flagitio...

Que não só exigem menos como farão um serviço muito mais justo, e sem escândalo!

Mas esta pregação enfrenta graves problemas de mudança de costumes, onde percebemos, para incredulidade de alguns, que também as honestas se entregavam ao sexo livre (fr.29.81 $=868-9 M)^{42}$ :

At non sunt similes, neque dant - Quid? Si dare uellent acciperesne? Doce!

"Pois estas não são desse tipo e não se dão!" - "Como?! Se se dessem, aceitavas ou não? Diz-lá”.

Mas nos textos de Lucílio que chegaram até nós, mais do que os perigos do adultério com matronas, são apresentados os inconvenientes do casamento, entre eles a lubricidade e o adultério feminino. É o caso de uma velha cujo marido, por vingança, e em clara inversão do que a lei lhe consentia, se autoimola (fr.7.11 = 279-281M) ${ }^{43}$ :

Hanc ubi uult male habere, ulcisci pro scelere eius, testam summit homo Samiam sibi, anu noceo, inquit, praecidit caulem testisque una amputat ambo.

Quando decide fazer-lhe mal, vingar-se do seu crime, o homem agarra num vaso de Samos e diz "Vou dar cabo da velha"! E corta pela raiz o órgão e, de um só golpe, amputa os dois testículos.

Tão drástica decisão parece não ser adoptada por um outro, mas a imagem de uma virilidade passiva mantém-se (fr.7.12 = 282-3M):

Dixi. Ad principium uenio; uetulam atque uirosam uxorem caedam potius quam castrem egomet me.

Merc. 1015-1023, Propércio, 2.24, sem esquecer a comédia (cf. F. Oliveira 2006b, para Terêncio: os amores entre jovens e cortesãs são tidos como iniciação sexual e sentimental, prelúdio para o casamento).

${ }^{42}$ Para além da latomia de adultério de matronas nos elegíacos, implícita no já versado motivo dos perigos do adultério, recordo somente Propércio, 3.3.47-50, 3.13.23-34; Marcial, 4.71: nenhuma casada diz não.

${ }^{43} \mathrm{O}$ tema é já glosado em P1. Merc. 275: Quasi hircum metuo ne uxor me castret mea; cf. Catulo, 63.5 refere um caso de automutilação ritual com sílex; para Horácio, S. 1.2.44-45, esse é um dos riscos do adúltero apanhado em flagrante; cf. Valério Máximo, 6.1.13. Fiske 1966: 259 e 354 n.103 admite que a leitura de tibi por mibi permitiria interpretar como castigo do adúltero. 
Já disse. Volto ao princípio: com uma esposa velha e corredora de homens ${ }^{44}$, prefiro espetá- $1 \mathrm{a}^{45}$ a castrar-me a mim mesmo.

Em época de crise de virilidade, não admira sequer que apareça um marido chulo e complacente, como no fr.5.23 = 206-7M:

\section{Absterge lacrimas et diuos ture precemur, consilium fassi, placeatne inpune luperis.}

Acaba com as lágrimas e, com incenso, perguntemos aos deuses, confessando o nosso intento, se podes prostituir-te sem ser punida.

Esta sugestão de adultério, que poderá também constar dos fr.5.22 = 208$209 \mathrm{M}$ e 5.28 = 216-217M, antecipa a complacência dos maridos da elegia latina, num passo cuja concisão parodia o motivo do sono do marido enganado (fr.H.67): non omnibus dormio 'não me ponho a dormir para qualquer um!'46

Um outro lugar-comum, para todas as classes de mulheres, refere-se à higiene. Neste aspecto, o livro VII, que terá constituído uma verdadeira arte de amar, abordaria todos os requintes da toilette e da moda $(7.1=264-265 \mathrm{M})$, e a higiene $($ fr.7.2 $=266 \mathrm{M})$, com um ideal de beleza e sensualidade $(7.3=268 \mathrm{M})$ que Ovídio retomará ${ }^{47}$.

O motivo da falta de higiene e da fealdade, já entrevisto no fr.15.13 = 504-5M e eventualmente nos fr.30.81 = 1067M (perolesse 'feder'), está bem assinalado no fr.26.20 = 599-600M. Para Terêncio, essa é uma mazela de meretrizes, que, cheias de pompa na rua, em casa vivem na maior imundície ${ }^{48}$. Em Lucílio, a repulsão é acentuada por aliterações, repetições, negações e paralelismo sintáctico:

squalitate summa ac scabie summa in aerumna obrutam, neque inimicis inuidiosam neque amico exoptabilem.

Toda coberta de porcaria e toda coberta de imundície, na maior das desgraças, não sendo merecedora da inveja dos inimigos nem atraente para os amigos.

${ }^{44}$ Virosa 'corredora de homens' tem sentido sempre negativo: cf. Afrânio, Diuortium 62-64, fr.62 Ribbeck; equivale ao mulierosus 'mulherendo' de Afrânio, 369.

${ }^{45} \mathrm{O}$ sentido erótico de caedam é garantido por Catulo, 56.7; J. N. Adams 1982: 145: "Caedo sometimes implies a sexual act seen as punishment ... pedicatio".

${ }^{46}$ Para a relação sono do marido / traição, cf. Tib. 1.6.27; Ov. Am. 3.5. Sobre marido ou amante complacente no código elegíaco, ver Catulo, 17 e 68b.147-148; Tib. 1.6 (verdadeira paródia do tema), Ovídio, Am. 2.19, 3.12.11: me lenone; Ars 2.372 e 539 ss.; M. Labate 1984: 66-67 e 100-104: o amante elegíaco chega a ter traços de gigolo.

${ }^{47}$ Terêncio, $E$ u. 934-940 ("fora de casa ... não há nada mais asseado, mais sofisticado e mais elegante ... Mas ver a sua imundície, a sua sujidade, a sua miséria, como elas são repugnantes quando estão sozinhas em casa”, em trad. de A. Couto, Terêncio: O Eunuco, Lisboa, 1996); cf. Lucrécio, 4.1171-1191. Na fraseologia, Lucílio parece ter inspirado Tib. 1.8.40: nulli cupienda uiro, e Ov. Trist. 4.4.65-66: non inuidiosa nefandis / nec cupienda bonis.

${ }_{48}$ Sobre Frine (fr.7.4 = 263M), cf. Horácio, Epod.14.16; Tib. 2.6.45-54 (alcoviteria), Propércio, 2.6.6; Valério Máximo, 4.3.1; Plin. Nat. 34.70 (amante do escultor). 
Entre os símbolos do requinte contaria Frine, a cortesã ateniense do séc. IV aC que serviu de modelo a Praxíteles para a estátua de Afrodite ${ }^{49}$ e que parece representar a meretrix caprichosa, cheia de ademanes e adereços, cara e artificial (fr.7.4 $=263 \mathrm{M}$ e $7.1=264-5 \mathrm{M})^{50}$.

A toilette poderá eventualmente estar ligada a práticas fetichistas, como no fr.H.111 = 1161M, sobre as sandálias de Sícion ${ }^{51}$.

Num outro passo, a fealdade emparelha com idade provecta, cliché elegíaco omnipresente, com sugestão de monstruosidade e defeitos morais habituais em velhas prostitutas baratas (fr.30.80 $=1065-6 \mathrm{M})$ :

illo quid fiat, Lamia et Bitto oxyodontes
quod ueniunt, illae gumiae uetulae inprobae ineptae?

Que importa que apareçam uma Lâmia e uma Bito de dentes afiados, umas glutonas decrépitas, falsas, imbecis?

Sendo certo que as casadas traziam os seus atributos físicos recatados, é normal que cuidassem os aspectos exteriores para compensar. Mas nem as próprias matronas deixam de merecer o reparo da falta de asseio (fr.30.83 = 1047M: haec uestimentis maculosis. - Tum aspice sis te 'Essa roupa cheia de manchas' - 'Então olha por ti abaixo!').

Assim, o fr.15.13 = 504-5M apresenta-nos uma esposa frívola, que só se atavia para receber algum estranho, situação claramente característica do mundo romano, onde a mulher estava presente quando se acolhiam visitas masculinas não pertencentes à família:

cum tecum est, quiduis satis est; uisuri alieni

sint homines, spiram, pallas, redimicula promit.

Quando está só contigo, qualquer farrapo serve. Mas se vai receber homens de fora, areja anéis, mantilhas, braceletes ${ }^{52}$.

\section{Blanda uoluptas em Lucrécio}

A temática do amor em Lucrécio é tão importante que figura logo na portada da obra, sob o lema do prazer (v.1.1: uoluptas; cf. 4.1057: namque uoluptatem praesagit muta cupido; 2.171: dux uitae dia uoluptas), num hino a

${ }^{49}$ Essa beleza artificial (cf. Fiske 1966: 269-270) seria contraposta a um tipo de beleza mais natural, masculino ou feminino (fr.7.5 e 8 = 271 e 269-270 M); cf. Fr.D.1, sobre a mulher lacónia. Tib. 1.8.15 e 43 ss. reserva a necessidade de toilette para amantes de idade avançada; Prop. 1.2.5: naturae decus mercato perdere cultu, 2.18.25: pintura do cabelo; 3.24.8: quaesitus candor in ore.

${ }^{50}$ Cf. Lucr. 4.1125; os vestidos transparentes de Cós eram outro símbolo frequente de luxo e devassidão.

${ }^{51}$ Fiske 2611-262: a beleza das mulheres casadas "rests on their external surroundings".

52 Para a moda em Roma, incluindo nomes de origem estrangeira, ver Plin. Nat. 8.190-197, 9.117-121; também Tib. 1.9.65-74 e Juvenal, 6.464-5 relacionam luxo do vestuário com mulher lasciva e adúltera, que só se enfeita para o amante, não para o marido. 
Vénus Genitriz, ao seu poder criativo, à sua força e à sua vitória sobre Marte. Como escreve Brown, o desenvolvimento funde análise filosófica, capacidade de observação, sátira e ornamentos poéticos num resultado praticamente único na poesia latina ${ }^{53}$.

O tema assume depois cariz concreto num trecho altamente sugestivo do livro IV (v.1030-1287). O passo abre com a descrição do impulso sexual na puberdade (v.1046: dira lubido), a significar que é natural e físico, quase mecânico (v.1056), e que, por vezes, levado por simulacros de beleza de outro ser humano, o sémen, espalhado por todo o corpo (cf. v.1042), corre involuntariamente durante a noite, manchando as vestes (v.1030 ss.; v.1036: seminis ingentis fluctus uestemque cruentent $)^{54}$.

Logo nesta fase o homem aparece como vítima do desejo sexual (v.1049: uulnus; 1050 e 1052: ictus; 1055: feritur $)^{55}$ suscitado pela beleza de um corpo (v.1053-4: siue puer membris muliebribus hunc iaculatur/seu mulier toto iactans e corpore amorem).

Com esta explicação racionalista, Lucrécio fornece uma verdadeira definição (4.1058-1059):

Haec Venus est nobis; binc autemst nomen amoris, binc illaec primum Veneris dulcedinis in cor stillauit gutta et successit frigida cura.

É isto Vénus, para nós. Daqui sai o nome de amor, daqui correu para o coração aquela primeira gota da doçura de Vénus, a que sucedeu um gélido cuidado ...

Está dado o mote para dois aspectos: a doçura (Veneris dulcedinis) e a coita de amor (frigida cura), contrária ao ideal de ataraxia ${ }^{56}$. Quanto à primeira, há que procurá-la; quanto à segunda, há que evitá-la através da satisfação das pulsões sexuais no primeiro corpo disponível, praticando uma medicina da paixão que leva a desviar-se do objecto do amor procurando outro qualquer objecto substituto (iteração de alio nos v.1064 e 1072; corpora quaeque no v.1065) e a praticar sexo de forma errante (v.1071: unlgiuagaque uagus Venere) ${ }^{57}$. É que amor, e em especial

${ }^{53}$ Brown 1987: 218.

${ }^{54}$ Para a relevância do tema do oneirogmos, cf. Brown 1987: 172-173; em AP 5.2 e 12.125 e 127 são relatados sonhos eróticos, ligados à polução nocturna, considerada morbus: cf. Aristóteles, HA 636b-638a (caso feminino); Lucílio, fr.H.73 = 1248M (perminxi lectum, inposui pede pellibus labes); Hor. S. 1.3.90: comminxit lectum potus. A teoria sobre a presença do sémen em todo o corpo deriva de Demócrito, foi adoptada por Epicuro (cf. Bailey 1986: 1303) e Lucr. 4.1215 ss. e 5.851-852. helenística.

${ }^{55}$ Brown 1987 ad 1049-1057 põe em relevo a linguagem militar, na tradição da poesia

${ }^{56}$ Ver Brown 1987 ad 1060.

${ }^{57}$ Cic.Tusc. 4.65 ss. trata da cupiditas e de ética sexual, com passagem pelos clichés do drama e da poesia elegíaca; ver em especial 4.74 ss. (remédios do amor) e 5.94 (prazeres sexuais são fáceis e comuns); cf. Prop. 1.5: Non est illa uagis similis collata puellis; 2.25.40-48 e 3.14.21-32: os costumes espartanos tornariam os cânones do amor elegíaco obsoletos. 
o amor único e exclusivo (v.1066: unius amore), é sinónimo de cura, dolor, ulcus, furor, aerumna, uulnus, plaga, animi motus (v.1060-1072), numa sequência onde a terminologia médica se mistura com lugares-comuns da doença do amor ${ }^{58}$.

A distinção entre uenus 'sexo, prazer sexual' e amor 'amor, paixão amorosa' (4.1073: Nec Veneris fructu caret is qui uitat amorem) permite defender as vantagens do amor sem os seus inconvenientes (v.1074: sine poena commoda), numa antítese psicológica traduzida pelo confronto sanus / miser (4.10751076), que no desenvolvimento sobre o frenesim sexual logo se transforma em oposição entre pura ou blanda uoluptas (respectivamente 4.1075 e 1085$)^{59}$ e amor enquanto paixão destruidora e insaciável (cf. 4.1102), descrita por conceitos derrogativos onde predominam as ideias de paixão, dor, esforço e violência (error, ardor, dolor, laedere, rabies, morsus, dira cupido, laborare, uis, uiolens, rabies, furor, cupere, malum, labor), as metáforas do fogo (flamma, ardescere, ignis), da falta de rumo (recorrência de incertus nos v.1077, 1104 errantes, 1120), da luta (pugna, certare, uulnus) e de uma sede como a de Tântalo ${ }^{60}$.

De especial relevância, assinalada pela anáfora adde (4.1121-1122), é a súmula dos inconvenientes e perigos do amor (v.1121-1140): a debilitação (v.1121)L; a dependência de outrem ou servidão amorosa (4.1122: alterius sub nutu ${ }^{61}$; a cegueira dos amantes (v.1153: cupidine caeci); a dilapidação dos bens (1123: res) e da fama (1124: languent officia atque aegrotat fama); a vida de lazer (1131: conuiuia, ludi) e o luxo excessivo, traduzido por referências exóticas e vocabulário que sugere amor meretrício, como Babylonica, Sicyonia, anademata, mitrae, Alidensia, Cia, com perigo de perda do património familiar (4.1129: bene parta patrum) ${ }^{62}$; tudo isso agravado por incerteza, angústia (4.1135: conscius ipse animus se forte remordet), humilhação e ciúmes (4.1133-1140).

Contra este quadro desolador das consequências de uma paixão sem rejeição (v.1141: amore proprio summeque secundo), Lucrécio vai retratar o amor romântico, infeliz (v.1142: in aduerso uero atque inopi), numa perspectiva mais tradicional do que filosófica, com inspiração em Platão e Teócrito ${ }^{63}$. A medida necessária para evitar os males dessa situação é expressa por metáfora cinegética que parodia o topos tradicional: não se deixar apanhar nas redes da sedução $0^{64}$;

${ }^{58}$ Brown 1987 ad 1068-1072; Flury 1968. O tema do amor exclusivo aparece em versão acaso homoerótica, em $A P 5.232$ e 12.105, e supõe o amor multívago, como em Prop. 2. 23, 24 e 25 .

${ }^{59}$ Ocorrências de blanda uoluptas em 2.966, 4.1263, 5.178; cf. 1.19: blandum amorem.

${ }^{60}$ Lucr. 4.1097-1100: in medioque sitit torrenti flumine; cf. AP. 5.218, 220, 246, 12.175; Prop. 2.17.5-6; 3.5.42 sitis inter aquas; Tib. 1.3.77-78; Ov. Am. 3.12.30: in medio Tantalus amne sitit, Met. 9.761: mediis sitiemus in undis.

${ }^{61}$ Cf. Prop. 2.25.11: duro seruire tyranno; cf. AP 12.169.

${ }^{62}$ A enumeração dos gastos e luxos, em 4.1125-1132, além de conter vários topoi cómicos, tem ressonâncias da Roma coeva, como observa Brown 1987: 250; para bene parta, Bailey 1986 ad 1129 estabelece paralelo com Ter. Ph. 788; cf. Pérsio, 5.164: rem patriam; para mitra como adereço de meretriz estrangeira, ver Juv. 3.66.

${ }^{63}$ Brown 1987 ad 1141-1191.

${ }^{64}$ Brown 1987 ad 1146-1150: "Lucretius is turning a conventional image of amatory literature against amor by bringing out its sinister implications"; exemplos do topos venatório na literatura latina: P1. Epid. 216 retia, Mil. 608 uenator adsit cum auritis plagis, Trin. 237 plaga; 
mais ainda, evitar a cegueira dos amantes quanto ao carácter e ao físico da amada e quanto aos seus defeitos físicos (4.1151 ss.: animi uitia ... corporis ... prauas turpisque), cegueira que provoca irrisão (4.1157: alii irrident $)^{65}$. O trecho é o seguinte (4.1141-1156):

Atque in amore mala baec proprio summeque secundo inueniuntur; in aduerso uero atque inopi sunt, prendere quae possis oculorum lumine operto, innumerabilia; ut melius uigilare sit ante, qua docui ratione, cauereque ne inliciaris. nam uitare, plagas in amoris ne iaciamur, non ita difficile est quam captum retibus ipsis exire et ualidos Veneris perrumpere nodos. et tamen implicitus quoque possis inque peditus effugere infestum, nisi tute tibi obuius obstes et praetermittas animi uitia omnia primum aut quae corpori' sunt eius, quam praepetis ac uis. nam faciunt homines plerumque cupidine caeci et tribuunt ea quae non sunt bis commoda uere. multimodis igitur pranas turpisque uidemus esse in deliciis summoque in honore uigere.

E tais mazelas são fruto de um amor sólido e bem feliz; mas num amor adverso e desgraçado, são inumeráveis, e podes vê-las de olhos vendados; assim, é melhor estar antecipadamente de aviso, pela razão que expus, e procurar não ser enredado.

Evitar cair nas redes do amor não é tão difícil como, depois de apanhado, sair dessas mesmas redes e romper os fortes laços de Vénus. E, todavia, mesmo enlaçado e enredado, ainda podes escapar desse perigo, desde que a ti próprio não cries obstáculos, e não desculpes, primeiro, todos os defeitos da alma ou do corpo que possui aquela que tanto procuras e desejas. É isto o que fazem, no geral, os indivíduos cegos de paixão, que thes atribuem qualidades que elas realmente não têm. Por isso vemos mulheres feias e com deformidades gozar de predilecção e do mais alto apreço.

Ov. Am.1.8.69 retia, Ars 1.45 ss. scit bene uenator ... ubi retia tendat, 263, 270, 2.2 decidit in casses, 3.554 nouus viso casse resistet amans; cf. Bailey ad 1146.

${ }^{65}$ C. Bailey 1986 ad.1160-1169 e ad 1164 em especial, sugere paráfrase de fonte literária grega, tendo em conta o acerbo de termos gregos e a forma verbal traulizi, sem excluir o tratado de Epicuro sobre o amor. O tema dos defeitos físicos já vem de Platão, R. 474de, incluindo o topos da condescendência do apaixonado; Theocr. 6.18 (muitas vezes o amor faz parecer belo aquilo que o não é), 10.24-27; $A P$ 5.89: amar mulher feia é que é verdadeiro amor. Em autores latinos, ver Hor. S. 1.3.43 ss. (aplicado a relações pai / filho e entre amigos); Ov. Ars 2.641-662, inclusive a acostumação aos defeitos (v.654: quo fuit uitium, desinit esse mora), em Rem.291-356, a consideração dos defeitos da amada funciona como terapia amorosa, embora por vezes o amor aceite os defeitos (v.350: fallit enim multos forma sine arte decens; cf. 707-714). 
A irrisão decorre da inversão da realidade, que toma a fealdade por beleza, na continuação de um trecho onde não repugna a utilização de grecismos ${ }^{66}$, que em todo o caso não iludem a sátira e a ironia (4.11571170):

atque alios alii irrident Veneremque suadent ut placent, quoniam foedo adflictentur amore, nec sua respiciunt miseri mala maxima saepe. nigra melichrus est, immunda et fetida acosmos, 1160 caesia Palladium, neruosa et lignea dorcas, paruula, pumilio, chariton mia, tota merum sal, magna atque immanis catalepsis plenaque honoris. balba loqui non quit, traulizi, muta pudens est; at flagrans odiosa loquacula Lampadium fit. ischnon eromenion tum fit, cum uiuere non quit prae macie; rhadine uerost iam mortua tussi. at tumida et mammosa Ceres est ipsa ab Iaccho, simula Silena ac saturast, labeosa philema. cetera de genere hoc longum est si dicere coner.

E uns riem-se dos outros e incitam-nos a acalmar Vénus quando são atormentados por um amor repugnante, e, coitados, amiúde não enxergam os seus males extremos. Se é morena, é mel; imunda e mal cheirosa, é natural; de olhos glaucos, é Palas; pele e osso, uma gazela; uma baixita, anã, é uma gracinha, puro charme; a alta e enorme, é um espanto, de pose senhoril. A gaga, incapaz de articular, tem voz peculiar; a muda, é pudica; quanto à arrebatada, à odiosa, à de língua afiada, torna-se Fogo. Em coisinha fofinha se torna a que não consegue viver de tão cansada; é uma verdadeira delicadeza a que morre de tosse. Mas a avantajada e de mamas enormes, é Ceres em pessoa aleitando Íaco; de nariz abatatado, uma Silena, uma sátira; de grandes lábios, é um amor. Longo seria tentar desfiar todas estas baboseiras.

${ }^{66} \mathrm{O}$ uso de grecismos (melichrus, acosmos, Palladium, dorcas, chariton mia, catalepsis, traulizi, Lampadium, ischnon eromenion, rhadine, ab Iaccho, Silena, satura, philema), uma mistura de nomes próprios ou apelidos e de nomes comuns, terá a ver com as fontes gregas e com o facto de muitas cortesãs serem gregas (cf. Filodemo $A P$ 5.132, parece contrapor às gregas uma rameira romana; Prop. 2.23.21 e Juv. 3.62 ss. referem-se a rameiras orientais). Segundo Juv. 6.184-199, a própria linguagem do amor é grega. Para o trecho de Lucrécio apontamos os seguintes paralelos: Aléxis 98K, provável fonte de Lucrécio (preocupação das heteras com a beleza; AP 5.182, de Meleagro, para dorcas 'gazela'; $A P$ 5.177-179, Eros é simos, um termo de larga tradição para descrever um nariz que é símbolo de sensualidade; $A P 5.210$ amor por uma melaina; $A P 12.51$ (amado agrada a um, não a outro); AP 12.94 e 95 (variedade da beleza); Lucil. 304-6M, 540-6M; Ter. Hau. 1060-1061 (adulescens recusa uma noiva rufa e caesia); Hor. S. 1.3.38-; Prop. 2.25.41-45; Ov. Am. 2.4.9-48 (qualquer mulher agrada, sem cânone definido de beleza); Ars 2.641 ss., 657 ss., 3.293 ss., Rem. 323 ss., Ep. 4.73 ss., 15.31 ss.; Mart. 10.68.5. Sobre a opção pelos helenismos em Horácio, cf. Rudd 1966: 111 ss. 
Apesar da toada satírica, Lucrécio tem a sensatez de reconhecer que a beleza é subjectiva e que a notação dos defeitos pode não ter força suficiente (v.1171-1172) ${ }^{67}$. Em congruência, rompem novos argumentos, elencados com um sugestivo tricolon: que existem outras (aliae do v.1173 retoma a já referida iteração de alio); que se viveu sem ela até ao momento; que ela tem as mesmas mazelas das torpes, a começar pelo mau cheiro, numa clara identificaçção entre meretrix e scortum (4.1174-1176).

Numa paródia do tema do paraklausithyrion, segue-se o quadro antitético e fortemente satírico do exclusus amator, a chorar junto à porta soberba, enchendo-a de ósculos, de unguentos e de coroas de flores ${ }^{68}$, com suas tristezas já bem gravadas nas elegias que preparou ${ }^{69}$, mal sabendo que, se fosse admitido (oposição exclusus / admissus), logo uma baforada o dissuadiria e lhe faria descobrir a sua estultice $(4.1177-1184)^{70}$. E mais uma vez, num gesto de humanidade e realismo, Lucrécio observa que a própria beldade procura esconder essas mazelas do homem que pretende acorrentar, mas que este, disfarçando o riso, até pode ser condescendente (4.1171-1191) ${ }^{71}$ :

sed tamen esto iam quantouis oris honore,
cui Veneris membris uis omnibus exoriatur:
nempe aliae quoque sunt; nempe hac sine uiximus ante;
nempe eadem facit, et scimus facere, omnia turpi,
et miseram taetris se suffit odoribus ipsa
quam famulae longe fugitant furtimque cachinnant.
at lacrimans exclusus amator limina saepe
floribus et sertis operit postisque superbos
unguit amaracino et foribus miser oscula figit;
quem si, iam ammissum, uenientem offenderit aura
una modo, causas abeundi quaerat honestas,
et meditata diu cadat alte sumpta querela,
stultitiaque ibi se damnet, tribuisse quod illi
plus uideat quam mortali concedere par est.
nec Veneres nostras hoc fallit; quo magis ipsae

sed tamen esto iam quantouis oris honore, cui Veneris membris uis omnibus exoriatur. nempe aliae quoque sunt; nempe hac sine uiximus ante; nempe eadem facit, et scimus facere, omnia turpi, et miseram taetris se suffit odoribus ipsa 1175 quam famulae longe fugitant furtimque cachinnant. at lacrimans exclusus amator limina saepe floribus et sertis operit postisque superbos unguit amaracino et foribus miser oscula figit; quem si, iam ammissum, uenientem offenderit aura

${ }^{67}$ A descrição da mulher sensual, em 4.1054 e 1172 recorda Catulo, 86.

${ }^{68}$ Lucr. 4.1178-9 elenca lugares-comuns já atestados nos elegíacos gregos, incluindo Calímaco AP 5.23 e Asclepíades, AP 5.145, 153 e 189 (sobre a influência deste poeta, ver Gutzwiller 1998: 137 e 140-142), e com futuro nos latinos (desde Plauto, Merc. 405-409 e 418 a Ov. Am.1.6.1 ss.; Prop. 1.16; 3.3.47-50; Tib. 1.2), tal como o qualificativo de superbus.

${ }^{69} \mathrm{O}$ termo querela (cf. Catul. 64.195), pode evocar o tom lacrimoso do termo elegia, como em Prop. 1.16.13 e 39, 1.18.29, 2.18.1, Ov. Ars 1.657-660 (lágrimas de amante). Sobre o desenvolvimento, escreve Brown 1987 298: "Unlike the erotic poets, he sees no romance in the situation but merely a contrast between façade and reality which epitomizes his concept of love as an illusion".

${ }^{70}$ Em Ter. Eu. 923-940, Parmenão defende que um jovem apaixonado se cura quando conhece todas as mazelas das cortesãs (Nosse omnia haec salus est adulescentulis); cf. Ov. Rem. 315 ss., cf. 707-714; Ars 3.209-234, com tonalidade lucreciana inclusive na metáfora teatral, aconselha-se a amada a evitar que o amante veja as suas mezinhas de cosmética.

${ }^{71}$ Lucr.4.1185-1191; o riso ajusta-se à metáfora cénica postcaenia; outras referências teatrais: 4.75-83, 788-793, 978-983; o uso da 2a pessoa dá ao trecho uma tonalidade diatríbica. 
omnia summo opere hos uitae postascaenia celant quos retinere uolunt adstrictosque esse in amore, nequiquam, quoniam tu animo tamen omnia possis

protrahere in lucem atque omnis inquirere risus

et, si bello animost et non odiosa, uicissim

praetermittere <et> humanis concedere rebus.

Seja: tenha ela toda a beleza de rosto, emane de todos os seus membros o poder de Vénus.

Pois existem outras mais. Pois vivemos sem esta até agora.

Pois ela faz tudo, e sabemos que o faz, igual a uma reles:

a coitada sufoca-se a si própria com maus cheiros,

e as criadas fogem dela, para longe, a rir às escondidas.

Porém, em lágrimas, o amante excluído, amiúde atravanca

a soleira com flores e grinaldas e, aos gonzos altivos,

unge-os com manjerona; e as portas, coitado, cobre-as de beijos.

Se, já admitido, ao entrar o bafeja uma única baforada,

inventará boas razões para se pôr na alheta

e esquecerá as queixas bem meditadas e longamente preparadas,

e logo se censurará pela estultice de nela ter visto

mais do que é juz conceder a um mortal.

E isto não escapa às nossas Vénus; por isso elas mesmas mais

se esmeram a esconder todos estes bastidores aos amantes

que querem manter presos ao seu amor.

Em vão, pois que tu, com a tua inteligência, tudo podes

trazer para a luz e descobrir toda esta matéria de riso;

e, se ela for de bom coração e não odiosa, é caso

para esquecer <e> vergar-se à condição humana.

Serve este apontamento de transição para um verdadeiro elogio do intercâmbio sexual, desde que partilhado, o que implica a suposição de que, em princípio, as meretrizes são fingidas ${ }^{72}$. A descrição do amor carnal utiliza muitas expressões elegíacas e tem um pressuposto: havendo correspondência, existe prazer, e prazer mútuo, e amiúde a mulher é elemento activo da relação ${ }^{73}$. A prova da pulsão e da satisfação sexual mútua, um axioma da ética epicurista, é fornecida por exemplos do reino animal, onde a fêmea se compraz com o coito (v.1200: laeta), num trecho que, a avaliar pelo verso final, trata matéria claramente controversa $(4.1192-1208)^{74}$ :

${ }^{72}$ Lucr. 4.1192: Nec mulier semper ficto suspirat amore; Ov. Ars 3.797 ss. recomenda fingimento para agradar ao amante, conselho já dado aos homens em Ars 1.613 ss.

${ }^{73}$ Bailey 1986 ad 1199: é a atitude da mulher que está a ser descrita; ver 4.1040, 1192s. (v.1195: facit ex animo saepe); o apetite sexual feminino tem antecedentes mitológicos e é frequente na literatura (ver Prop. 3.19) e nos textos médicos gregos e latinos; cf. Brown ad 1209-1232; F. Oliveira 2008a.

${ }^{74}$ Como escreve Bailey 1986 ad 1192, a incapacidade de se libertarem implica prazer para ambos os sexos; para a analogia com animais, cf. Lucr. 5.849-854, Ov. Ars 1.279-282, 2.477-492, com claras tonalidades lucrecianas, Met. 9.731 ss., metamorfose de Ífis. 
Nec mulier semper ficto suspirat amore quae complexa uiri corpus cum corpore iungit et tenet adsuctis umectans oscula labris. nam facit ex animo saepe et communia quaerens gaudia sollicitat spatium decurrere amoris. nec ratione alia uolucres armenta feraeque et pecudes et equae maribus subsidere possent, si non, ipsa quod illarum subat ardet abundans natura et Venerem salientum laeta retractat. nonne uides etiam quos mutua saepe uoluptas uinxit, ut in uinclis communibus excrucientur? in triuiis quam saepe canes, discedere auentes diuersi cupide summis ex uiribu' tendunt, cum interea ualidis Veneris compagibus haerent! quod facerent numquam nisi mutua gaudia nossent quae iacere in fraudem possent uinctosque tenere. quare etiam atque etiam, ut dico, est communi' uoluptas.

Nem sempre suspira de amor fingido a mulher que, abraçada ao varão, une o seu corpo ao corpo dele e lhe dá beijos húmidos sugando-lhe os lábios. Pois amiúde o faz do coração e, procurando gozos partilhados, incita-o a percorrer o caminho do amor!

Não há outro motivo para as aves, as manadas e as feras e os rebanhos e as éguas se deixarem submeter aos machos a não ser a sua própria natureza, que se inflama, cheia de cio, e se compraz em estimular o sexo dos que as cobrem.

Acaso não vês até, amiúde, aqueles que o prazer mútuo venceu, sofrerem a tortura das uniões comuns?

Nas encruzilhadas quão amiúde os cães, incapazes de se separar, puxam ansiosamente, cada um para seu lado, com toda a força, mas ficam presos pelos fortes laços de Vénus!

Nunca tal aconteceria se não sentissem mútuo gozo, capaz de os lançar no engodo e de os manter agarrados. Por isso, digo e redigo, o prazer é partilhado.

A meu ver, a formulação conclusiva, em defesa do prazer partilhado, remete necessariamente para a procriação, já que, para algumas teorias científicas subjacentes, esta só se dava se houvesse prazer mútuo, como se depreende da ocorrência de blanda uoluptas em contexto de sexo conjugal e sob o ponto de vista feminino (4.1263), implicando a emissão mútua de fluidos germinais $^{75}$, preferentemente em posição de quadrúpede (4.1264-1267: more ferarum quadrupedumque magis ritu). O texto, onde se desenrola uma metáfora agrícola já presente em Lucrécio, recusa mesmo que, no sexo conjugal, que tem o privilégio distintivo de gerar cidadãos ${ }^{76}$, a mulher necessite de movimentos

${ }^{75}$ Lucr.4.1229: Semper enim partus duplici de semine constat, cf. 1209 ss. e Brown ad 12091232.

${ }^{76}$ F. Oliveira 2008a: 81-82; para o elogio do afecto familiar, ver Lucr. 1234; para os aspectos 
eróticos, próprios de scorta que querem evitar a gravidez e dar ao parceiro um prazer mais refinado, não em busca de prazer próprio $(4.1268-1277)^{77}$ :

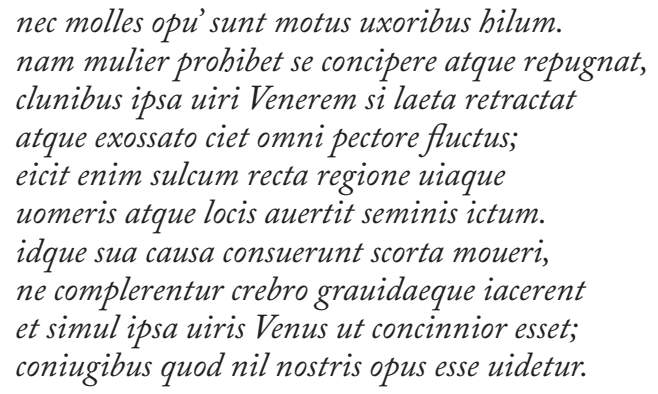

$\mathrm{E}$ as esposas para nada precisam de movimentos eróticos.

Uma mulher preserva-se e evita conceber se se compraz em estimular com as nádegas o prazer do varão, e provoca ondulação em todo o seu peito arqueado.

De facto, ela desvia o rêgo da direcção certa e do caminho do arado, e afasta das partes o jacto de sémen.

De igual modo, no seu interesse costumam as rameiras mexer-se para não ficarem sempre cheias e inactivas por gravidez, e para também a própria Vénus ser mais requintada para os varões; ora isto parece não ser nada necessário às nossas esposas.

Significativamente, no quadro de uma relação com uma mulher mediana, com a ocorrência dos termos muliercula (4.1279) e femina (v.1280) a nada conter de derrogativo, o livro IV encerra com o elogio do amor baseado na consuetudo, no bom carácter e no asseio, na linha da ética tradicional e da própria tradição elegíaca, acaso também por analogia com a concepção epicurista de amizade $^{78}$, o que parece remeter para a existência de amor na relação conjugal, assim reabilitada por oposição ao objecto da diatribe $(4.1278-1287)^{79}$ :

\section{Nec diuinitus interdum Venerisque sagittis deteriore fit ut forma muliercula ametur. nam facit ipsa suis interdum femina factis morigerisque modis et munde corpore culto,}

sociais da procriação, cf. v.1256 (munire senectam); a metáfora agrícola dos v.1272-1273 evoca Lucr. 4.1107 (muliebria arua) e Ver. G. 3.135 (genitali aruo et sulcos); com o seu interesse social, Lucrécio "speaks more as a Roman paterfamilias than as the Epicurean philosopher" (Bailey 1986: 1316).

${ }_{77}$ Não admira que Tib. 1.9.64-65 trate de uma esposa que aprendeu tais movimentos com um amante.

${ }^{78}$ Bailey 1986: 1319, que, todavia, ad 1279, considera depreciativa a ocorrência de muliercula; ad 1280-2 evoca Afrânio 372-373: aetas et corpus tenerum et morigeratio, / haec sunt uenena formosarum mulierum.

${ }^{79}$ Brown 1987 372; a metáfora final, correspondente ao ditado português "água mole em pedra dura ...”, é um topos elegíaco (cf. Tib.1.4.18, Prop. 2.25.16, Ov. Ars 1.475-476, Rem. 692). 
ut facile insuescat <te> secum degere uitam. quod superest, consuetudo concinnat amorem; nam leuiter quamuis quod crebro tunditur ictu, uincitur in longo spatio tamen atque labascit. nonne uides etiam guttas in saxa cadentis umoris longo in spatio pertundere saxa?

$\mathrm{E}$ acontece, não por graça divina, não pelas setas de Vénus, uma mulherzinha de beleza medíocre por vezes ser amada. É que por vezes essa própria mulher, com suas acções, com seus bons modos e com seu físico bem cuidado, faz com que facilmente <te $>$ acostumes a viver com ela. Além disso, a habituação suscita o amor; o que é repetidamente atingido por um golpe mesmo leve, a longo termo é vencido e cede.

Não vês como até as gotas de água que sobre pedra caem, a longo termo furam essa pedra?

Este fecho, claramente contraposto à exposição anterior, ao distinguir entre relacionamento matrimonial prolongado e encontros casuais para satisfazer necessidades físicas através de sexo comprado, consagraria a ausência do topos do adultério, de acordo com o ensinamento de Epicuro ${ }^{80}$.

\section{Horácio e o meio termo no amor}

A partir da referência à morte do pródigo Tigélio, Horácio desenvolve em S.1.2, uma série de contrastes entre modos de vida diversos, como a oposição entre o indivíduo que só pensa em adultério com mulheres casadas (1.2.28-29: sunt qui nolint tetigisse nisi illas / quarum subsuta talos tegat instita ueste), qual Pirgopolinices plautino, e aquele que prefere mulheres da vida (v.30: contra alius nullam nisi olenti in fornice stantem), as que constituíam a salvaguarda do casamento, já dizia Catão, na esteira de Sólon ${ }^{81}$.

O tema desenvolve-se de forma a aliar a vertente filosófica a temáticas herdadas tanto da comédia plautina e terenciana, como da elegia amorosa, em ambos os casos com seus modelos gregos ${ }^{82}$.

${ }^{80}$ Cf. DL.10.118 e Filodemo, AP 5.46; sobre sexo fácil entre Cínicos, Estóicos, Epicuristas, Comédia Nova, moral tradicional romana, Antologia Palatina, Lucílio, Propércio (cf. 2.23, por oposição aos perigos do adultério, e 2.24.9), ver Brown 1986: 198-199.

${ }^{81}$ Horácio, S.1.2.31-35; cf. Fiske 1966: 253 ss.

${ }^{82}$ O próprio Horácio, $S .1 .2 .16$-22 parafraseia Terêncio e relaciona Lucílio com o riso do mimo de Labério (S.1.10.6); recorda o cómico Fundânio, arguto como uma cortesã (S.1.10.4042); o Davo de S. 2.7 é o típico seruus callidus da comédia (Muecke 1993 ad 2); cf. Pérsio, 5.161. Prop. 2.6.3 e 4.5.44-45, considera a Taís de Menandro como modelo de cortesãs e elogia o comediógrafo em 3.21.18; Ovídio Ars 3329 ss. inclui Menandro entre os poetas eróticos; Rudd 1966 115, recorda Lucílio como "a quasi-dramatic author writing in a genre akin to comedy"; Frécaut escreve 1972: 229-230 que o tema da lição de amor já se desenha na comédia nova, no epigrama alexandrino e em Plauto e Terêncio; cf. Gutzwiller 1998: 295-296. Em termos genéricos, pode dizer-se que a sátira é herdeira da invectiva nominal da comédia antiga. 
Na vertente filosófica, salienta-se a ideia de que a pulsão sexual, corresponde a um desejo natural e é fácil de satisfazer (v.64-79) ${ }^{83}$, desde que não procure prazer misturado com dor (v.39: multo corrupta dolore uoluptas), não ceda a imaginações que contrariem a natureza (v.105-118) e não dilapide o património com mimas e libertas (v.47-63) ${ }^{84}$. Além disso, sobre o adultério com matronas impendem perigos reais, desde a frustração causada quando a nudez vem revelar defeitos físicos até aí escondidos (v.80-104), ao contrário do que se passa com o amor comprado a uma liberta, cuja nudez tudo revela desde o início, até aos riscos de se ser apanhado em flagrante adultério (v.41-46, 58-67 e 119-134) ${ }^{85}$.

Depreende-se deste breve resumo que a tonalidade epicurista do amor fácil e a custo baixo, do prazer alcançado sem empenhamento afectivo, pode ser conjugado com valores tradicionais da sociedade romana ${ }^{86}$. Não falta sequer um aceno a alguma tonalidade estóica, logo na ocorrência de stult $^{87}$. Nem mesmo se pode irradiar a pregação cínica em favor das ligações ocasionais ${ }^{88}$.

Quando se desce à análise de pormenor, todo o raciocínio consiste num defesa da justa medida no comportamento sexual, na linha da definição aristotélica de virtude como meio termo. Isso é logo visível em S.1.2.28-30, quando se opõe o indivíduo que só gosta de mulheres com longos vestidos de matronas (v.29 e 99) ${ }^{89}$, àquele a quem só interessa frequentar prostíbulos mal cheirosos, designados pelo termo fornix (v.30 e 31).

A breve trecho a sátira vai fazer o elogio do amor vulgar, pago a baixo custo, e, sintomaticamente, coloca-o sob a autoridade do guardador-mor das virtudes tradicionais romanas, Catão, tolerante com lupanares (S. 1.2.33-35):

"nam simul ac uenas inflauit taetra libido, huc iuuenes aequom est descendere, non alienas permolere uxores".

${ }^{83} \operatorname{Ver} S$. 2.2.8-22 para o elenco de prazeres que resultam da satisfação de desejos naturais de forma simples.

${ }^{84}$ Sobre o relacionamento com libertas, cf. Rudd 1966 11-12 ("simple anthitesis of the matrona").

${ }^{85}$ A lex Iulia de adulteriis coercendis de $18 \mathrm{aC}$, ao classificar pela primeira vez o adultério como crime, limitou o exercício do direito pelo paterfamilias, como lembra Brown 1993 ad 4146; cf. Muecker 1993 ad S. 2.7.61 ss.; Rudd 1966: 227.

${ }^{86}$ Cf. S.1.2.39: uoluptas; daí as reservas quanto a mimas e libertas de elevado custo. Também Propércio 2.22.35-42 advoga a coexistência de várias amantes e, em 2.23, de baixa condição.

${ }^{87} \mathrm{Ver}$ S.1.2.24: dum uitant stulti uitia, in contraria currunt 'ao procurarem evitar certos vícios, os estultos caem nos vícios contrários”; é que um stultus de modo algum pode alcançar a virtude.

${ }^{88}$ Rudd 1966: 25; quanto à diatribe cínica em matéria de ética sexual, Oltramare 1926 regista os temas 23: a beleza não é um bem; 23a: a beleza feminina é um perigo; 32: satisfazer as necessidades sexuais da forma mais comum possível; 32a: evitar o adultério; 32b: não recorrer a meretrizes caras; 32c: recorrer a prostitutas de baixa condição; 32d: recorrer à masturbação; 87: o amor-paixão é um mal.

${ }^{89}$ S.1.2.29: quarum subsuta talos tegat instita ueste; v. 99: ad talos stola demissa et circumdata palla; Tib. 1.6.68; Prop. 1.4.14: gaudia sub tacita dicere ueste libet; Ov. Ars 1.31-32: Este procul, vittae tenues, insigne pudoris, / quaeque tegis medios, instita longa, pedes!; Am. 3.36: quae bene sub tenui condita ueste latent. O registo do vestuário já se encontra em Afrânio, 153: Meretrix cum veste longa? 'Uma meretriz com vestuário comprido'? 
"De verdade, logo que a terrível libido incha as suas veias, é vantajoso que os jovens aí se dirijam, para não molestarem as esposas alheias”.

Mas nem todos assim pensam, a começar por Cupiénio, que prefere buracos protegidos por roupa branca, isto é, sexo com matronas que se vestiam com a stola alba (v.71). Está dado o mote para uma exposição sobre os perigos do adultério $(S .1 .2 .42-47)^{90}$ :

Hic se praecipitem tecto dedit, ille flagellis ad mortem caesus, fugiens bic decidit acrem praedonum in turbam, dedit hic pro corpore nummos, bunc permixerunt calones; quin etiam illud accidit ut quidam testis caudamque salacem demeret ferro.

Este atirou-se do telhado, aquele foi zurzido à vergastada até à morte, ao fugir este caiu no meio de um agressivo bando de salteadores, este pagou bom dinheiro para salvar a pele, a este urinaram-lhe em cima os criados. Aconteceu pior: alguém lhe cortou rente os testículos e o penduricalho infame.

Em vista de tais perigos, parecerá mais segura a mercadoria da segunda classe ( $S .1 .2 .47$ ss.), ou seja, a classe das libertas. Fica assim estabelecida uma hierarquia das parceiras sexuais que deixa adivinhar o fecho da sátira ${ }^{91}$. Dois exemplos revelam que também há perigos nesta classe: o de um Salústio que dilapidou o património com prendas exorbitantes à sua amada, protegido com uma convicção de moralidade ( $S$. 1.2.54: Matronam nullam ego tango 'Eu não toco em nenhuma matrona'); e o de Marseu, que proclamava nada querer com esposas alheias, mas com mimas e meretrizes (v.58), tendo gasto com a mima Origo o património herdado do seu pai (v.56; cf. v.62).

Estes dois exemplos são claros: o mal consiste em perder o bom nome ou o património, seja com uma matrona seja com uma criadita que se entrega à prostituição (v.63 matrona, ancilla ... togata $)^{92}$. Também esta conclusão é ilustrada com o exemplo de Vílio, apanhado em flagrante adultério com Fausta, filha de Sila, e severamente castigado pelo marido desta (S.1.2.66-72):

... pugnis caesus ferroque petitus, exclusus fore, cum Longarenus foret intus.

buic si muttonis uerbis mala tanta uidenti

${ }^{90}$ Cf. S. 1.2.37-40: laborent, dolore, pericla; o termo ferrum recorre em S. 1.2.47, 66; 2.7.58; Juv. 10.311-317: necat bic ferro. Cupiénio (lat. cupere, cupido) exemplificará o uso de nomesfalantes herdado de Lucílio (Rudd 1966: 143-146) e tradicional no teatro.

${ }^{91}$ Sobre a hierarquia paródica de amantes, cf. Lefèvre 1993: 94 e 192 ss.

${ }^{92}$ Cf. Tib. 3.16 (poema de Sulpícia), onde toga se relaciona com scortum. 
diceret haec animus: "quid uis tibi? numquid ego a te magno prognatum deposco consule cunnum uelatumque stola, mea cum conferbuit ira?" quid responderet? "magno patre nata puella est".

... desfeito à punhada e picado com aguilhão, posto fora da porta, quando Longareno estava lá dentro.

A esse, ao sofrer tais mazelas, se a sua consciência lhe transmitisse estas palavras do maganão: "Que querias afinal? Porventura eu exijo-te um cunnus herdeiro de um ilustre cônsul e escondido sob um vestido, quando o desejo me inflama?" - acaso responderia: "A rapariga é filha de um pai ilustre"?

Em terminologia de tonalidade epicurista, o autor observa que a natureza não exige canseiras nem coisas que se devem evitar, como o adultério com matronas (S.1.2.73-79).

Segue-se o tema da relação entre beleza e amor, a mostrar que têm vantagens acrescidas as amantes de baixa condição sobre as de alta estirpe. De facto, umas coxas ou umas pernas bem feitas não pertencem amiúde a damas elegantes, mas a mulheres da vida $(S .1 .2 .80-82)$, que trazem à vista tudo o que têm para vender (v.83-84: mercem sine fucis ... / quod uenale habet ostendit). Ao contrário, as matronas escondem os seus defeitos (v.85: turpia). Ora, como quem compra um cavalo, há que inspeccionar cuidadosamente a mercadoria, coisa impossível quando se trata de matrona $(S .1 .2 .86-93)^{93}$.

Segue-se o quadro antitético da matrona sempre rodeada de um séquito e escondida sob as suas vestes (S.1.2.94-100); e o da mercenária do amor que tudo desvela sob transparentes vestidos de Cós (S.1.2.101 ss.). Uma metáfora cinegética, herdada de Clímaco, sobre o caçador que recusa uma peça de caça já pronta, preferindo perseguir a lebre que se escapa entre as neves, ilustra a loucura de quem busca o inatingível e vão, se entrega a canseiras e dores, em vez de se alegrar com o que se lhe apresenta fácil $(S .1 .2 .114-119)^{94}$ :

num, tibi cum fauces urit sitis, aurea quaeris

pocula? num esuriens fastidis omnia praeter

pauonem rhombumque? tument tibi cum inguina, num, si

ancilla aut uerna est praesto puer, impetus in quem

continuo fiat, malis tentigine rumpi?

non ego: namque parabilem amo uenerem facilemque.

Acaso, quando a sede te queima a garganta, procuras taças

de ouro? Acaso, morto de fome, tudo enjeitas

a não ser pavão e rodovalho? Quando se te levanta o órgão,

${ }^{93}$ S.1.2.92 (o crus! o bracchia!) é paráfrase de Filodemo, AP 5.132; cf. Ov. Am. 1.5.19-22.

${ }^{94}$ Calímaco, $A P$ 12.102; ver também $A P$ 12.173. Ovídio, Am. 2.9.9-10; cf. 2.19.36: quod sequitur, fugio; quod fugit, ipse sequor. Quanto ao amor pederástico (cf. S. 2.3.325), ele aparece como natural, a exemplo de Lucrécio 4.1053. O pavão, símbolo de luxo gastronómico também é referido em S.2.2.23. 
tendo ao teu dispor uma criada ou um jovem escravo, no qual de imediato possas descarregar, preferes rebentar de tesão? Eu não! É que gosto de prazer venéreo pronto e fácil.

Esta comparação com a sede e a fome implica o registo filosófico epicurista dos desejos naturais e necessários (cf. v.73-76; cf. S.1.49-51, 75), logo confirmado com citação de Filodemo: à mulher casada é preferível uma profissional de preço módico, que vem logo que é chamada, bem feita, arranjada, mas sem excessos de toilette ou maquilhagem, com uma beleza natural; essa é a parceira preferida, uma Ília ou uma Egéria, dê-se-lhe o nome que se quiser; com ela os perigos do adultério não existem, o que é recordado numa verdadeira composição em anel reminiscente das cenas de mimo (S.1.2.127-134) ${ }^{95}$ :

$$
\begin{aligned}
& \text { nec uereor ne dum futuo uir rure recurrat, } \\
& \text { ianua frangatur, latret canis, undique magno } \\
& \text { pulsa domus strepitu resonet, uepallida lecto } \\
& \text { desiliat mulier, miseram se conscia clamet, } \\
& \text { cruribus haec metuat, doti deprensa, egomet mi, } \\
& \text { discincta tunica fugiendum sit, pede nudo, } \\
& \text { ne nummi pereant aut puga aut denique fama. } \\
& \text { deprendi miserum est; Fabio uel iudice uincam. }
\end{aligned}
$$

nem receio, enquanto a monto, que o marido regresse do campo, a porta seja arrombada, ladre o cão, e com grande estrépito, por todo o lado, a casa ressoe; que, palidíssima, do leito salte a mulher, se proclame desgraçada a cúmplice, receosa esta pelas suas pernas, a apanhada em flagrante, pelo dote, eu, pela minha pessoa, e só reste fugir de túnica solta e pé descalço, para não desgraçar os cabedais, ou o traseiro, ou, enfim, a fama. Porca miséria ser apanhado! Nisto vencerei até o juiz Fábio!

O topos dos defeitos próprios e alheios, em toada contrária à igualdade dos erros defendida pelos estóicos, é o objecto da da Sátira 1.3, sobre a cegueira de um amante que não vê os defeitos da amada $(S .1 .3 .38-55)^{96}$ :

\section{Illuc praeuertamur, amatorem quod amicae} turpia decipiunt caecum, uitia aut etiam ipsa haec delectant, ueluti Balbinum polypus Hagnae.

Voltemos-nos antes para o seguinte: os defeitos da amada escapam ao amante cego, ou até chegam mesmo a agradar-lhe, como o pólipo de Hagna agradou a Balbino.

${ }^{95}$ Cf. Brown 1993 ad 127-134; sobre o tema da Venus parabilis, ver Rudd 1966: 24-25; para os castigos elencados, cf. Juv.10.306-317; para sexo com criada, Ov. Am. 2.7.17-28, 2.8, 3.6.47 ss. (sobre Ília), Ars 1.351 ss.

${ }^{96}$ Fiske 1966: 274, vê relação directa com Lucrécio (cf. 4.1149-1191). 
O tema é transposto para a relação entre amigos, onde se deve condescer, a exemplo de um pai que designa os defeitos dos seus filhos com eufemismos ou até os nobilita (S.1.41-54). Segue-se um tirada sobre as origens da humanidade, reminiscente de Lucrécio, onde se aflora o tema do adultério $(S \cdot 1 \cdot 3 \cdot 107-110)^{97}$ :

\section{(nam fuit ante Helenam cunnus taeterrima belli causa, sed ignotis perierunt mortibus illi quos Venerem incertam rapientis more ferarum uiribus editior caedebat, ut in grege taurus).}

(ora, antes de Helena, um cono foi a terrível causa da guerra, mas morreram de uma morte obscura por terem roubado uma Vénus incerta, à maneira das feras, esses a quem matou um dotado de mais força, como touro em rebanho).

$\mathrm{Na}$ Sátira 1.4, o poeta coloca-se como imitador da comédia antiga e de Lucílio, a reivindicar o direito de criticar adúlteros (v.4: moechus) que só cobiçam mulheres casadas (v.27: hic nuptarum insanit amoribus, bic puerorum $)^{98}$.

Numa discussão que tem a ver com questões de genologia literária, é referido entre os caracteres de comédia o adulescens perdido de amor por uma meretriz e, para desespero de seu pai, desinteressado do casamento com uma esposa de grande dote $(S .1 .4 .48-52)^{99}$.

Esta invectiva pessoal funciona como o exemplo negativo com que um pai pretende dissuadir seu filho de dilapidar o património e a fama no amor, num passo reminiscente de Terêncio $(1.4 .111-115)^{100}$ :

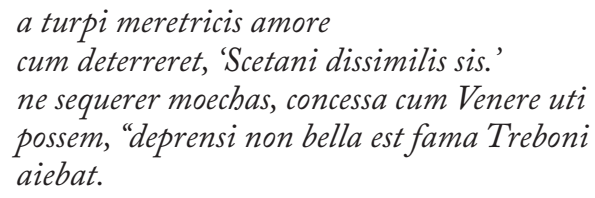

Do torpe amor por uma meretriz me afastava: "sê diferente de Cetano". Para eu não perseguir adúlteras, pois podia recorrer a prazeres venéreos permitidos, dizia: "não é bonita a fama de Trebónio, apanhado em flagrante”.

No domínio do amor, a S.1.5.82-85 recorda um sonho erótico, com consequente polução nocturna (v.85: nocturnam uestem maculant uentremque

${ }^{97}$ Lucr. 4.1201-1205 (sexo animal), e 5.783 ss., 925 ss., trechos que parecem o modelo de Ov. Ars 2.467-492, 621-624 quando se refere à humanidade primitiva.

${ }^{98}$ Ver Prop.2.4.17-18; a bissexualidade é tema corrente na Antologia Palatina (e. g.AP12.90).

${ }^{99}$ Cf. Terêncio, An. 191.

${ }^{100}$ Cf. S.1.4.105-126 e Terêncio, Ad. 413 ss.; Pérsio, 5.163 ss. 
supinum), provocado pela espera por uma jovem mentirosa que prometeu ir ao quarto do autor mas não apareceu ${ }^{101}$.

$\mathrm{Na}$ Sátira 1.6, graças à educação dada por seu pai, Horácio afirma ter evitado a ignomínia, em particular a decorrente da frequência de bordéis (v.68: mala lustra $)^{102}$.

Com temática de crítica literária, a Sátira 1.10, sem deixar de elogiar o papel de Lucílio como fundador do género, censura-o por misturar termos romanos com termos gregos (S.1.10.20-21: quod uerbis graeca latinis miscuit) e por usar um tom agressivo e rude (v.65).

$\mathrm{Na}$ Sátira 2.3, Damasipo vitupera o modo de vida de Horácio e lembra que o estóico Estertínio proclamava que todos os homens são loucos (2.3.32; cf. 1.3.24), isto é, vítimas de paixões (S.2.3.79-80: luxuria ... / aut alio mentis morbo). Entre elas enumera a luxuria e, na sua proximidade, a paixão amorosa, um transporte pueril exemplificado pelo merectricis amore (v.250-252; cf. 1.2.58; 1.4.49). Segue-se uma paráfrase do Eunuco de Terêncio sobre o tema do exclusus amator, do paraklausithyrion, dos tormentos e da cura dos males de amor $(S .2 .3 .258-271)^{103}$ :

... amator

exclusus qui distat, agit ubi secum, eat an non 260 quo rediturus erat non arcessitus, et haeret inuisis foribus? "nec nunc, cum me uocet ultro, accedam? an potius mediter finire dolores? Exclusit; reuocat. redeam? non si obsecret." ecce seruus non paulo sapientior: "o ere, quae res nec modum habet neque consilium, ratione modoque tractari non uult. in amore haec sunt mala, bellum, pax rursum.

... Em que se diferencia

o amante despedido, quando matuta se deve ou não entrar, sem ser chamado, aonde tinha intenção de retornar, e fica especado diante das portas odiadas? "E agora que é a primeira a chamar-me, não vou entrar?! Não será melhor pensar em pôr fim às minhas dores? Despediu-me, torna a chamar-me. Torno a entrar? Não, mesmo que suplique". Logo o escravo, com mais sabedoria, e não é pouca: “Ó patrão, o que 265

${ }^{101}$ Comparar com Asclepíades, AP 5.150.

${ }^{102}$ Ver S.1.4.107-115; e 1.6.82-84 para pederastia nas escolas, atestada na Antologia Palatina e noutros autores.

${ }^{103}$ Terêncio, Eu. 46-81; o Hautontimoroumenos fora referido em S.1.2.20-22; cf. Tib. 2.6.13: Iuraui quotiens rediturum ad limina numquam!; a utilização de material cómico aparece em $S$. 2.5.91: Dauus sis comicus; $1.4 .45-56$ revela as preocupações de um pai com os desvarios do apaixonado adulescens da comédia, a exemplo de Pl. Merc. 40-110; eventual evocação de cenas de comédia e mimo em S. 2.7.53 ss. (amante travestido e clausus in arca); cf. Prop. 2.6.14 (rival escondido debaixo de uma túnica) e 2.15.30: uerus amor nullum nouit habere modum, 3.19.4: nescitis captae mentis habere modum (libido feminina); Pérsio, 5.161 ss., esp. 172-173, com paráfrase similar. Para além de Lucrécio, poderá haver influência de Cícero, Tusc.4.68 ss. (cf. Muecke 1993 ad 258-271). 
não tem regra nem discernimento, não é com razão e com regra que pode ser tratado. No amor, os males são assim: guerra e depois paz.

Nesse domínio, Horácio acaba por se considerar estulto e até insano (v.305-306). E Damasipo irá acusá-lo de ser vítima de furor por mil donzelas e por mil rapazinhos (v.325) ${ }^{104}$. De permeio, fica a notação irónica de um marido enganado pela esposa com suas escapadelas nocturnas (v.238: unde uxor media currit de nocte nocata).

$\mathrm{Na}$ Sátira 2.5,Tirésias convida Ulisses a portar-se como marido complacente (facilis), para captar a benevolência de um velho rico e putanheiro (scortator), pondo em causa a fidelidade de Penélope, assim comparada a uma mulher de vida, que só não teria pecado por falta de ocasião. É que os pretendentes estavam mais interessados em comida do que em sexo (S.2.5.73-83) $)^{105}$.

$\mathrm{Na}$ Sátira 2.7, no quadro da liberdade própria das Saturnais e em fraseologia estóica e cínica, Davo desenrola o tema da servidão para dizer que Horácio, escravo das suas paixões, é menos livre do que ele. Demonstra assim que não são iguais todos os erros (cf. S.1.3.96). Na linha de S.1.2, mas com linguagem menos obscena, depois de uma alusão ao moechus Prisco (v.8-14), sob o tema geral da servidão, são confrontados dois tipos de amor, o adultério e o amor livre de cuidados $(S \cdot 2.7 .46-56)^{106}$ :

'Te coniunx aliena capit, meretricula Daumm;
peccat uter nostrum cruce dignius? acris ubi me
natura intendit, sub clara nuda lucerna
quaecumque excepit turgentis uerbera caudae
clunibus aut agitauit equum lasciua supinum,
dimittit neque famosum neque sollicitum ne
ditior aut formae melioris meiat eodem.
tu, cum proiectis insignibus, anulo equestri
Romanoque habitu, prodis ex iudice Dama
turpis odoratum caput obscurante lacerna,
non es quod simulas?'

'A ti uma esposa alheia te cativa, a Davo uma simples meretriz.

Qual de nós dois merece mais a cruz com tal pecado? Quando se entesa

${ }^{104}$ Cf. Hor. S. 1.4.27; Prop. 2.4.17-18.

105 Rudd 1966: 234-235 vê aqui um tratamento paródico da figura de Ulisses e Penélope. Cf. AP 9.166; Lucílio, 17.3 (538-539M); Ov. Ep.1.84: Penelope coniunx semper Vlixis ero; Am.1.8.43 e 47-48: casta est quem nemo rogavit /... / Penelope iuvenum vires temptabat in arcu; / qui latus argueret corneus arcus erat (para o sentido erótico de latus, cf. Lucílio, fr.8.2 = 305 M), Ars 1.477 (a sua fidelidade pode ser vencida), 2.355 e 3.15-16 (exemplo de fidelidade, tal como em Prop. 3.12.38 e 13.24, mas não em 4.5.7). Ver também Sen. Ep. 88.8.

${ }^{106}$ Para o uso de supinus (S. 2.7.50), cf. Adams 1982: 165 ss. (ver supra n.39); a sugestão de que a mulher se porta como cavaleira, já presente em AP 5.203 e Catul. 32 (cf. Gutzwiller 1998: 126), também está ligada ao termo clunes 'ancas, nádegas' (cf. Lucr. 4.1270; Hor. S. 2.7.50; Juv.6.19, com latus). 
a violenta natureza, na claridade de uma lanterna aquela que, nua, recebeu as investidas do meu membro túrgido ou, lasciva, com suas nádegas excitou o garanhão, pondo-se por cima, essa larga-me sem eu ficar com má fama ou com receio de que um mais rico ou de maior beleza aí venha ejacular. $\mathrm{Tu}$, arrojando as insígnias, o anel de cavaleiro e a veste de cidadão romano, passando de juiz a um ignóbil Dama, a cabeça perfumada escondida debaixo da lacerna, não és aquilo que simulas ser?'

Depois deste quadro antitético entre um amor às claras ${ }^{107}$ e um amor às ocultas, segue-se, em tonalidade epicurista, a descrição dos perigos do adultério, com seus castigos psicológicos e legais, em especial se houver flagrante delito $(S .2 .7 .56-70)^{108}$ :

metuens induceris atque

altercante libidinibus tremis ossa pauore.

quid refert, uri uirgis ferroque necari

auctoratus eas an turpi clausus in arca, quo te demisit peccati conscia erilis,

contractum genibus tangas caput? estne marito

matronae peccantis in ambo iusta potestas?

in corruptorem uel iustior; illa tamen se

non habitu mutatue loco peccatque pudice,

[cum te formidet mulier neque credat amanti]

ibis sub furcam prudens dominoque furenti

committes rem omnem et uitam et cum corpore famam?

Euasti: credo, metues doctusque cauebis:

quaeres quando iterum paueas iterumque perire

possis, o totiens seruus!

Medroso, deixam-te entrar e alternando a libido com o pavor, tremes até aos ossos.

Que difere seres vergastado ou passado pelo fio da espada, como gladiador contratado, ou, enclausurado numa ignóbil arca onde te encerrou uma escrava cúmplice do delito,

segurares a cabeça apertada entre os joelhos? Não tem o marido

da matrona pecadora, sobre os dois, o direito do seu lado?

Com mais razão sobre um sedutor. Ora não é ela que

muda de vestuário ou sai do seu lugar ou peca, por pudor,

[pois, sendo mulher, fê-lo por medo, não se entregou a um amante);

irás para a forca, tu que és prudente, e a um senhor em fúria

entregarás todos os teus bens, e a vida e, com o teu corpo, a fama?

${ }^{107}$ S. 2.7.48: sub clara nuda lucerna; amor e nudez à vista são elogiadas por Prop. 2.2.16, inclusive com recorrência de lucerna. Cf. Ov. Ars 1.245, 3.751; Marcial 10.38.7; ver AP 5.7, 8, 128, 197; Juv.11-172-173. O antropónimo Dama ocorre em Pérsio, 5.76.

${ }^{108}$ Rudd 1966: 192: "while the Cynics and Epicureans condemned adultery because of its risks, the Stoics concentrated on the anhealthy state of the offender's soul". 
Safaste-te? Irás ter medo e, com a lição, tomar cautela. Penso eu! Pois irás procurar ocasião para de novo te poderes aterrorizar e de novo desgraçar, ó mil vezes escravo!

No final do texto, para além do carácter compulsivo da paixão pelo adultério, fica lançada a imagem do seruitium amoris, depois desenvolvida na comparação estóica do amante que é por outrem manobrado como uma marioneta, acaso herdada de Calímaco (S.2.7.81-82: 'alii seruis miser atque / duceris ut neruis alienis mobile lignum' ${ }^{109}$.

O quadro da insania é completado com nova cena da perturbação do amante, ao gosto da comédia $(S .2 .7 .89-94)^{110}$ :

poscit te mulier, uexat foribusque repulsum

'quinque talenta

perfundit gelida, rursus nocat: eripe turpi

colla iugo; "liber, liber sum", dic age: non quis.

urget enim dominus mentem non lenis et acris

subiectat lasso stimulos uersatque negantem.'

'Cinco talentos

é quanto exige essa mulher que te vexa e te encharca, fora da porta, com água fria, rejeitando-te, para de novo te chamar. Liberta desse ignóbil jugo o teu pescoço! "Sou livre, livre!”, vá, exclama! Não consegues.

É que domina a tua mente um senhor que não é brando, antes, severo, te submete ao aguilhão quando cansado e te faz arripiar quando te negas'.

\section{Conclusão}

A análise do tratamento satírico da temática amorosa em Lucílio, Lucrécio e Horácio, numa perspectiva de intertextualidade que abarca outros poetas, logo mostra que no tema confluem a lírica grega arcaica e a poesia helenística, a comédia nova e inclusive a togata romana, bem como perspectivas filosóficas de Platão, dos cínicos, do epicurismo e do estoicismo, sem esquecer a ideologia tradicional de Roma tanto em questões de moralidade ou fama como em questões de património ou res. É a síntese destas influências que constitui a memória poética na qual todos participam, reutilizam e recriam de forma mais ou menos subtil, por vezes até provocatória, o que em si mesmo é uma herança de Calímaco e Alexandrinos ${ }^{111}$.

Mas qualquer abordagem pertinente deve ainda considerar a base sociológica dos lugares-comuns da literatura, traduzida na progressiva emancipação da mulher, visível em Roma desde as Guerras Púnicas, mas já precedida por uma tradição que afirmava o carácter selvagem e desabrido da

${ }^{109} \mathrm{O}$ topos da marioneta virá de Platão, Leis, 644d-645c; cf. Pérsio 5.128-129.

110 A referência à moeda grega, como na palliata, também evoca os cinco talentos de Filodemo, AP 5.126. Cf. Prop. 2.5.14: iniusto subtrahe colla ingo.

${ }^{111}$ Ver Boyd 1997: 32 ss. 
sexualidade feminina, com reflexos na poesia helenística ${ }^{112}$ e destinada a tender, com Lucrécio e o Ovídio, para a plena igualdade da mulher como amante em sentido activo, mesmo quando a lírica ainda privilegia a tradição da expressão amorosa no masculino.

É esta vertente sociológica que permite compreender, por exemplo, o tema luciliano da automutilação do marido da adúltera, ou a ênfase que coloca nos defeitos e gastos das uxores, e não tanto das cortesãs, bem como a importância dada à toilette pelas matronas, impedidas que estavam de mostrar logo os atributos femininos.

De igual feição, temas como o seruitium amoris, o paraklausithyrion, as lágrimas e o qualificativo miser para o amator ou amans, a sua cegueira perante os vícios e defeitos femininos, têm de ser colocados sobre o pano de fundo de uma amada que é e se sente domina, e que já na Antologia Palatina reinvindicava o direito de ter outros amantes ${ }^{113}$.

Horácio está na charneira de todas estas confluências, tão bem sumariadas na sátira lucreciana do livro IV, e foi ele que soube encontrar o meio termo entre o carácter desabrido de Lucílio, a sua preocupação com uma linguagem mais vernácula e menos brejeira, o tom mais civilizado e de confronto de ideias, que nos ajudam a compreender os diversos enfoques em topoi como a cura da paixão através da separação ou do afastamento, a meditação sobre a experiência vivida, a tolerância perante os defeitos.

Em conclusão, penso poder afirmar que toda a temática e até o vocabulário já estavam fixados nos três autores estudados, permitindo aos elegíacos latinos, para além de variantes assumidas como desvios, paródia ou ruptura, concentrarem-se mais em formas de expressão do amor até aí menos seguidas, apenas esquissadas ou quase sem representação, como a arte de amar e as cartas de amor.

6. Bibliografia (para além das edições, Budé, Loeb, Oxford e Teubner)

J. N. Adams (1982), The Latin Sexual Vocabulary. London.

A. Alvar Ezquerra, "Intertextualidad en Horacio", in D. Estefania ed., Horacio el poeta y el hombre. Madrid, 77-140.

B. Arkins (1993), “The cruel joke of Venus: Horace as love poet”, in N. Rudd ed., Horace 2000: a Celebration. Essays for the Bimillenium. London, 106119.

C. Bailey, ed. (1986), Titi Lucreti Cari De rerum natura libri sex, vol.III. Oxford, 1947 re-issued.

${ }^{112}$ Cf. Gutzwiller 1998: 129 ss., onde enfatiza a importância do epicurismo nessa evolução e a sua influência sobre Asclepíades; nas p.157-169 assinala a coloração estóica de Posidipo.

${ }^{113}$ Asclepíades AP 5.158; cf. Gutzwiller 1998: 134-137 e 147, para a expressão feminina do amor. 
B. W. Boyd (1997), Ovid's Literary Loves. Influence and Innovation in the Amores. Ann Arbor.

R. P. Brown (1987), Lucretius on Love and Sex. Leiden.

P. M. Brown (1993), Horace: Satires. I. Warminster.

F. Charpin, Lucilius, Satires, 3 vols., Paris, 1978, 1979 e 1991 (edição utilizada e compulsada na anotação).

J. V. Cody (1976), Horace and Calilmachean Aesthetics. Bruxelles.

D. Feeny (1993), "Horace and the Greek Lyric Poets", in N. Rudd ed., Horace 2000: a Celebration. Essays for the Bimillenium. London, 41-63.

G. C. Fiske, Lucilius and Horace: a Study in the Classical Theory of Imitation. Hildesheim, 1920, repr.

M. Flury (1986), Liebe und Liebessprache bei Menander, Plautus und Terenz, Heidelberg.

J.-M. Frécaut (1972), L'esprit et l'bumour chez Ovide. Grenoble.M. Gigante (1987), La bibliothèque de Philodème et l'épicurisme romain. Paris.

A. S. Gratwick (1982), "The satires of Ennius and Lucilius" in E. J. Kenney and W. V. Clausen, eds, The Cambridge History of Classical Literature. II. Latin Literature, Cambridge, 156-171.

R. L. Gregoris (2002), El amor en la comedia latina. Análisis lexico y semántico. Madrid.

P. Grimal (1991), O amor em Roma. São Paulo.

K. J. Gutzwiller (1988), Poetic Garlands. Hellenistic Epigrams in Context. Berkeley.

D. Konstan (1973), Some aspects of Epicurean Psychology. Leiden.

D. Konstan (1986) "Love in Terence's Eunuch: The Origins of Erotic Subjectivity", AJPh 107.3 369-393.

M. Labate (1984) L'arte di farsi amare. Modelli culturali e progetto didascalico nell'elegia ovidiana. Pisa.

D. Leão (2002), "Legislação relativa às mulheres na Vita Solonis de Plutarco", in J. R. Ferreira (ed.), Plutarco Educador da Europa. Porto 81-91.

E. Lefèvre (1993), Horaz. Dichter im augusteischen Rom. München.

F. Muecke (1993), Horace, Satires II. Warminster.

F. Oliveira (2006a) “Misoginia em Terêncio”, Máthesis 15 83-107.

F. Oliveira (2006b), "Amor em Terêncio" in A. Pociña, B. Rabaza, M. F. Silva (eds), Estudios sobre Terencio. Granada 333-356. 
F. Oliveira (2008a), "Misoginia clássica. Perspectivas de análise”, in C. Soares I. C. Secall - M. C. Fialho, Norma e Transgressão. Coimbra 65-91.

F. Oliveira (2008b), “Misoginia na comédia togata”, Lisboa (no prelo)

F. Oliveira (2008c), “Temática feminina em Lucílio”, Revista Letras. Campinas (no prelo).

A. Oltramare (1926), Les origines de la diatribe romaine. Genève.

I. Opelt (1965), Die lateinischen Schimpfwörter und verwandte sprachliche Erscheinungen. Heidelberg.

P. Fedeli - A. A. Nascimento (2002), Propércio, Elegias. Lisboa.

N. Rudd (1966), The Satires of Horace. Cambridge.

P. H. Schrijvers (1970), Lucrèce. Amsterdam.

W. Stroh (1993), "De Horati poesi amatoria”, in Atti del Convegno di Venosa, 51-179.

L.P. Wilkinson (1985), Golden Latin Artistry. Cambridge, 1963 repr.

G. Williams (1968) Tradition and Originality. Oxford.

R. Winkes (1985), The Age of Augustus. The Rise of Imperial Ideology. Louvainla-Neuve. 